\title{
37. A TECTONIC CROSS-SECTION OF THE COSTA RICAN PACIFIC LITTORAL AS A KEY TO THE STRUCTURE OF THE LANDWARD SLOPE OF THE MIDDLE AMERICA TRENCH OFF GUATEMALA ${ }^{1}$
}

\author{
Jacques Azéma, Jacques Bourgois, Peter O. Baumgartner, Jean Tournon, Alain Desmet, and Jean Aubouin²
}

\begin{abstract}
Pre-upper Senonian basement of Costa Rica crops out in the Santa Elena and Nicoya peninsulas. From south to north and from base to top the basement includes the Esperanza, Matapalo, and Santa Elena units. The Esperanza unit is Albian-Santonian in age and consists mainly of pillow basalt and massive basalt flows. The Matapalo unit includes Callovian-Cenomanian radiolarite and exhibits a massive basalt flow, pillow basalt, and dolerite basement. The Santa Elena unit contains ultramafic and mafic rocks in which harzburgite is the major component. The most important tectonic features of the Nicoya Complex are the large Santa Elena and Matapalo nappes. Nappe emplacement was from north to south during late Santonian time. The sedimentary cover of the Nicoya Complex comprises (1) the Campanian El Viejo Formation, which consists of shallow-water sediments to the north on Santa Elena Peninsula and the Campanian-Maestrichtian Sabana Grande Formation of deep-water origin to the south on Nicoya Peninsula; (2) Paleocene sediments, which indicate deposition in a deep-water environment and which comprise the Rivas, Las Palmas, and Samara formations; and (3) post-upper Eocene(?) sediments, which consist of the shallow-water Barra Honda and Montezuma formations. Two unconformities are the major geologic features of the upper Senonian-Tertiary sequence of Costa Rica. The lower one is at the base of the Sabana Grande Formation and marks a major change in the geologic conditions (basalt is scarce in the Campanian-Tertiary series); the upper unconformity at the base of the Barra Honda and Montezuma formations is not as pronounced as the lower one. During post-Campanian time, normal faulting occurred in two stages separated by a phase of strong erosion.

The geology of the landward slope of the adjacent Middle America Trench is outlined in this chapter through interpretation of multifold seismic reflection records taken off the west coast of Costa Rica and from the DSDP Legs 67 and 84 transects off Guatemala. The western Caribbean Plate boundary may have been under extensional stress for the last $75 \mathrm{~m} . \mathrm{y}$. The strong landward-dipping reflectors of the landward slope of the Middle America Trench off Guatemala could be equivalent to the on-land pre-Campanian overthrusts of Costa Rica. The available data are consistent with the convergent extensional margin concept.
\end{abstract}

\section{INTRODUCTION}

The Middle America Trench is a convergent plate boundary that marks the subduction of the Cocos Plate beneath Central America and Mexico. The convergence rate is about $9.4 \pm 0.3 \mathrm{~cm} / \mathrm{yr}$. at an azimuth of $\mathrm{N} 30^{\circ} \mathrm{E}$ (Minster and Jordan, 1978; McNally and Minster, 1981) in the Guatemala transect region. Seaward on the Cocos Plate the aseismic Tehuantepec Ridge divides the Trench into two parts. The northwest part is the Acapulco Trench studied during Leg 66 (Moore et al., 1979), and the southeast part is the Guatemala Trench studied during Legs 67 and 84 (von Huene et al., 1980; Aubouin, von Huene et al., 1982a, b). A late Oligocene-early Miocene age for the subducting Cocos oceanic crust off Guatemala is well supported by the seafloor magnetic anomalies (Hey et al., 1977) and by findings from Leg 67 drilling off Guatemala (Aubouin et al., 1979). The Seabeam survey of Legs 67 and 84 areas (Aubouin, Stephan, et al., 1982) shows a horst and graben pattern on the Cocos

\footnotetext{
${ }^{1}$ von Huene, R., Aubouin, J., et al., Init. Repts. DSDP, 84: Washington (U.S. Govt. Printing Office).

2 Addresses: (Azéma, Bourgois, Aubouin) Département de Géotectonique, Université Pierre et Marie Curie, T. 26, 1st floor, 4 Place Jussieu, 75230 Paris Cedex 05, France; (Baumgartner) Escuela Centroamericana de Geologia, Universidad de Costa Rica, Ciudad Universitaria Rodrigo Facio, Apt. 35, San José, Costa Rica; (Tournon) Laboratoire de Pétrographie, Université Pierre et Marie Curie, T. 26, 3rd floor, 4 Place Jussieu, 75230 Paris Cédex 05, France; (Desmet) Laboratoire de Pétrologie, Faculté des Sciences, Université de Nancy I, B. P. 239, Vandoeuvre les Nancy Cédex 54506, France.
}

Plate that is oriented $140^{\circ} \mathrm{N}$ and thus oblique to the Trench (Fig. 1).

The Pacific Plate margin off Guatemala has been geophysically surveyed using seismic refraction, seismic reflection, and magnetic and bathymetric measurements (Ladd et al., 1982). Three different elements of the basement terrane have been defined by their "topographic" characteristics (von Huene et al., 1982): (1) a steep upper slope, (2) a rugged midslope covered by thick slope deposits, and (3) a smooth lower slope locally broken by benches. Landward-dipping reflectors proposed by Ladd et al. (1978) and Ibrahim et al. (1979) as evidence for a classic accretionary prism (Seely et al., 1974) are truncated by the rough midslope topography (von Huene et al., 1982). One of these acoustic basement reflectors was interpreted as a prominent unconformity by von Huene et al. (1982) and was drilled during Leg 84; this interpretation is supported by results from Site 569 where amphibolites (Bourgois et al., this volume) were drilled beneath lower Eocene-Pliocene slope sediments. Upslope in Hole 570 , a basal conglomerate of the slope sediment of early Eocene age was recovered; it overlies serpentinite basement. At the foot of the lower slope at Site 567 mafic and ultramafic basement was drilled below an Upper Cretaceous limestone that we assume to be in place. Thus the Leg 67 and 84 transects across the Guatemala Trench have defined a presently nonaccretionary convergent margin (Aubouin, von Huene et al., 1982a, b; Au- 


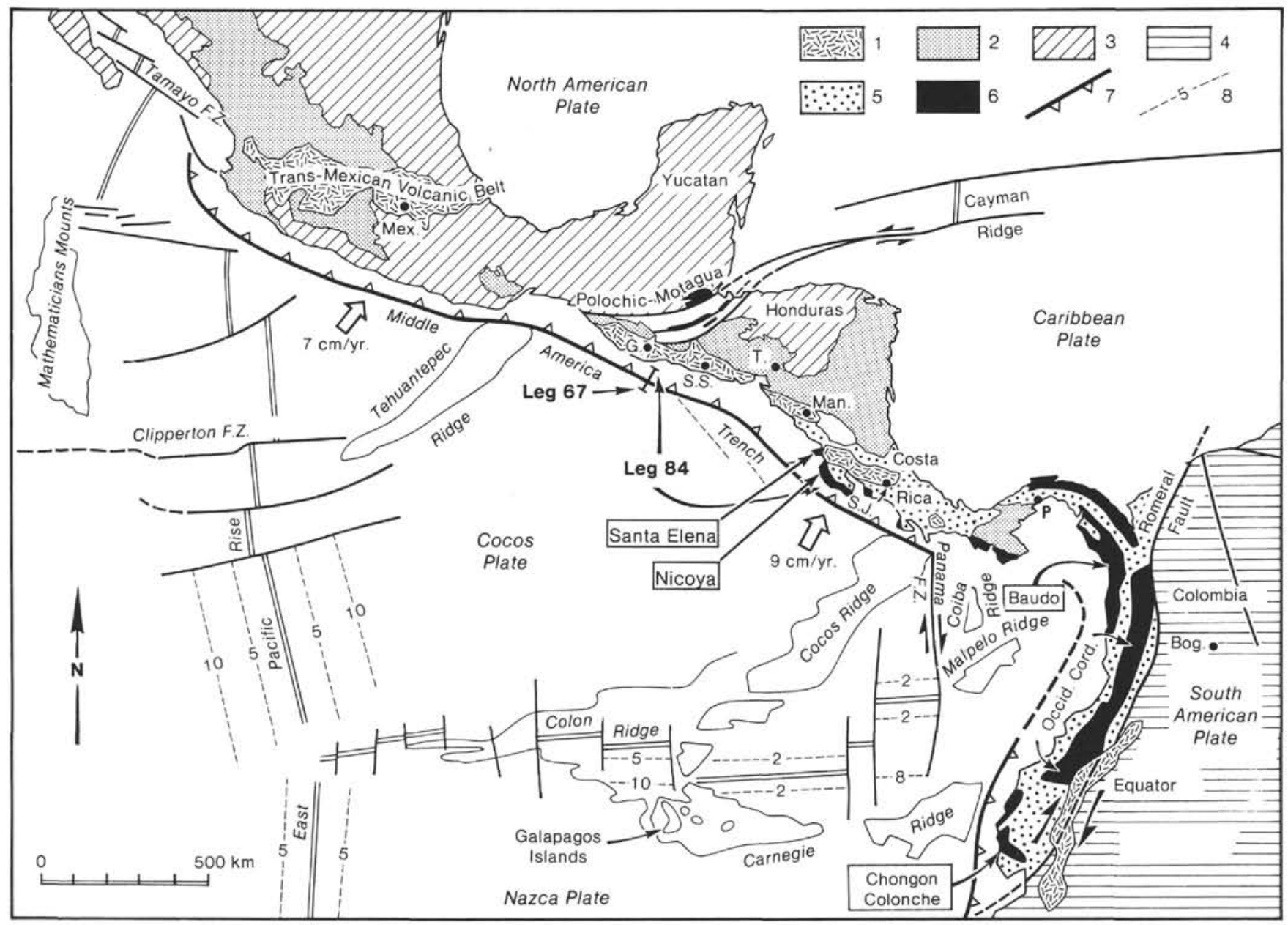

Figure 1. Tectonic setting of the Santa Elena and Nicoya peninsulas (Costa Rica) and of Legs 67 and 84 off Guatemala. Present-day plate motions from Minster and Jordan (1978). (1) Pliocene and Pleistocene volcanism; (2) Oligocene and Miocene; (3) North American Plate; (4) South American Plate; (5) Cenozoic formations of ophiolitic Andes and southern Central America; (6) Mesozoic and Cenozoic ophiolitic complexes; (7) subduction zones; (8) magnetic anomalies.

bouin, Bourgois, et al., 1982, 1984) because the rocks below the lower Eocene ophiolitic rocks (Bourgois et al., this volume) of the Guatemala Plate margin are juxtaposed against the subducting Miocene Cocos Plate. A prominent pre-Eocene/post-Upper Cretaceous unconformity is also defined.

Seismic data collected off the west coast of Costa Rica (Shipley et al., 1982; Crowe and Buffler, unpublished; Buffler, unpublished) include seven dip lines that extend across the slope from the shelf to the Middle America Trench and three strike lines crossing the landward slope (see Fig. 9). Several general results from Buffler's work are (1) the oceanic crust of the Cocos Plate can be traced beneath the landward slope of the Trench for distances up to $60 \mathrm{~km}$, (2) the normal oceanic sedimentary section is being subducted, and (3) all dip lines record a strong reflector at the base of the slope sediments. Locally the acoustic basement can be traced throughout the shelf and slope; it is called the top of the "accretionary zone" (Buffler, unpublished) and could correspond to the top of the Nicoya Complex. If this is true, the slope sediments could be the Upper Cretaceous and higher sedimentary cover of the Nicoya Complex.
Central America is subdivided on the basis of crustal composition determined from on-land geologic studies into a northern part including Guatemala, Honduras, El Salvador, Belize, and Nicaragua and a southern part including Costa Rica and Panama. Northern Central America is a continental block considered to be tectonically part of North America (McBirney and Williams, 1965; Dengo, 1973). Costa Rica and Panama are thought to represent an uplifted oceanic slice (Lloyd, 1963; Weyl, 1964; Dengo, 1973; Case, 1974; Stibane et al., 1977; Schmidt-Effing, 1979; Galli, 1979; Kuijpers, 1980; Azéma and Tournon, 1980; Bourgois, Azéma, et al., 1982; Hein et al., 1983).

\section{REGIONAL GEOLOGY AND PREVIOUS WORK ON THE NICOYA COMPLEX OF COSTA RICA}

In Costa Rica the first geologic overview was provided by Dengo (1962a), and the most recently published geologic map was that of ICAITI (1968). The Nicoya Complex (Dengo, 1962a) has been divided into two major stratigraphic units (de Boer, 1979; Kuijpers, 1980; Schmidt-Effing et al., 1981; Bourgois, Azéma, et al., 1982). The lower stratigraphic unit has generally been interpreted 
as uplifted Lower-Upper Cretaceous oceanic crust (Galli, 1977; Kuijpers, 1980; Schmidt-Effing et al., 1981), which includes the Peridotites of the Santa Elena Peninsula (de Boer, 1979; Azéma and Tournon, 1980; Bourgois, Azéma, et al., 1982). The upper stratigraphic unit of the Nicoya Complex is not clearly defined, and its interpretation is controversial. De Boer (1979) describes the upper unit as a sequence of volcanic rocks intercalated with chert, tuffaceous sediment, and limestone and interprets it as part of a volcanic arc built on the oceanic crust of the lower unit. An upper stratigraphic unit in the Nicoya Complex was also described by Schmidt-Effing (1979). He has subdivided it into six "subcomplexes" that include pillow basalts with inclusions of sedimentary rocks ranging in age from Late Jurassic to Eocene. These subcomplexes were interpreted (Schmidt-Effing, 1979; Schmidt-Effing et al., 1981; Gursky et al., 1982) as an oceanic plateau built on the lower unit of the Nicoya Complex. Neither of these two interpretations proposes a major break induced by tectonic deformation during the Mesozoic and Cenozoic geologic history of the Nicoya Complex. The first to recognize a prominent unconformity in the Santa Elena and Nicoya peninsulas was Dengo (1962a). He suggested a major tectonic change between the Nicoya Complex and the Sabana Grande Formation. Kuijpers (1980) also subdivided the rocks of the Nicoya Peninsula into a Nicoya ophiolite complex and an "overlying series" of early Campanian-Pleistocene age. He described a prominent unconformity between these two rock units. On Santa Elena Peninsula, Harrison (1953), Dengo (1962a, b), and Azéma and Tournon (1980) described a cover of shallow-water sediments overlying the peridotites, which includes reef limestone. The unconformity between the peridotites and the sediments is marked by a basal conglomerate containing reworked peridotite pebbles.

A third interpretation for the upper stratigraphic unit is that of Lundberg (1982) who has proposed a trench slope origin of the sedimentary deposits within the $\mathrm{Ni}$ coya Complex with uplift by progressive deformation of an intraoceanic arc trench system during Late Cretaceous and Tertiary time.

The basement of Costa Rica crops out mainly on Santa Elena and Nicoya peninsulas. It includes harzburgite, gabbro, basalt, pillow basalt, and volcanic and oceanic sediments. The Santa Elena Peninsula is composed of mafic and ultramafic rock. The major component is harzburgite. It is generally agreed that the rocks of the Santa Elena Peninsula were a basal part of an ophiolitic sequence (Harrison, 1953; Dengo, 1962b; Azéma and Tournon, 1980). The occurrence of peridotite was thought to be related to the Clipperton Fault zone (Dengo, 1962b; Weyl, 1969). Another interpretation by de Boer (1979) proposes that the ultramafic rocks of Santa Elena Peninsula are exposed in a major suture zone between the Chortis and Noba blocks. Using magnetic studies he projects the suture eastward but not westward. Structural analysis by the Santa Elena peridotite, however, provides evidence for southward overthrusting (Azéma and Tournon, 1980, 1982; Bourgois, Azéma, et al., 1982) onto the radiolarites of the Rio Potrero Grande window. Thus, the occurrence of ultramafic rock on Santa Elena Peninsula can apparently not be related to a simple uplift.

Pre-upper Senonian lithologic units were clearly delineated by Kuijpers (1980) on northern Nicoya Peninsula. They include the Esperanza and Matapalo units (Kuijpers, 1980). Dengo (1962a) was the first to describe the "ophiolites" of the Nicoya Complex and to relate them to oceanic crust. Subsequently the Nicoya Complex has become a topic of various studies (Weyl, 1966, 1969; Henningsen and Weyl, 1967; Galli, 1977, 1979; Schmidt-Effing, 1979; Kuijpers, 1980; Azéma and Tournon, 1980, 1982; Gursky et al., 1982), and several hypotheses have been proposed to explain it: (1) an accretionary process (Galli and Schmidt-Effing, 1977; Galli, 1979); (2) a continuous sedimentation from Latest Jurassic through Cretaceous and Paleocene-Eocene time with intermittent volcanic activity above an aseismic ridge (Schmidt-Effing, 1979); (3) a polyphase mechanism involving obduction of an oceanic crust assemblage during late Santonian time (Esperanza unit) onto an older oceanic crust assemblage (Matapalo unit) (Kuijpers, 1980).

\section{THE NICOYA COMPLEX: JURASSIC- SANTONIAN ONSHORE HISTORY}

\section{The Esperanza Unit}

The exact thickness of the Esperanza unit (Kuijpers, 1980 ) is not known, but it is at least a few hundred meters. It consists mainly of basalt and ophitic diabase. South of the Nicoya Peninsula, the Esperanza unit is composed mainly of pillow basalt interbedded with a few massive basalt flows. Sparse associated sediments include siliceous limestone, chert, and radiolarite (Fig. 2). Locally the sediments contain radiolarian assemblages indicating Cenomanian-early Santonian age (Kuijpers, 1980). Twenty radiolarian samples from northwestern Nicoya Peninsula studied by one of the authors (P.O.B.) were mainly from Santonian assemblages. Late Albian ammonites from the southern Nicoya Peninsula were mentioned by Azéma, Sornay, et al. (1979). This Albian age is supported by radiolarian assemblages (De Wever, personal communication, 1983). In the Montezuma region, a Cenomanian-Turonian age is supported by microfauna assemblages found in pillow basalt sediments (Azéma and Tournon, 1979), as near Playa Junquillal (Schmidt-Effing, 1979).

In the Punta Gorda-Cartagena region, massive basalt flows are more prevalent than they are southward. Along the coast south of Punta Gorda, doleritic dikes intrude thinly bedded radiolarites causing slight deformation. These radiolarites have a maximum thickness of $10 \mathrm{~m}$ and contain radiolarian assemblages of Santonian age (P. Baumgartner, personal communication, 1983). At Huacas, similar radiolarites are associated with sills of dolerites with magnesian olivine (Table 1, column 10) and pyroxenic dolerites characterized by ovoid nodules of large bytownite crystals. In the southern Nicoya Peninsula, basalts that are commonly pillowed are tholeiites (Table 1, column 11) (Weyl, 1969; Pichler and Weyl, 1973). 


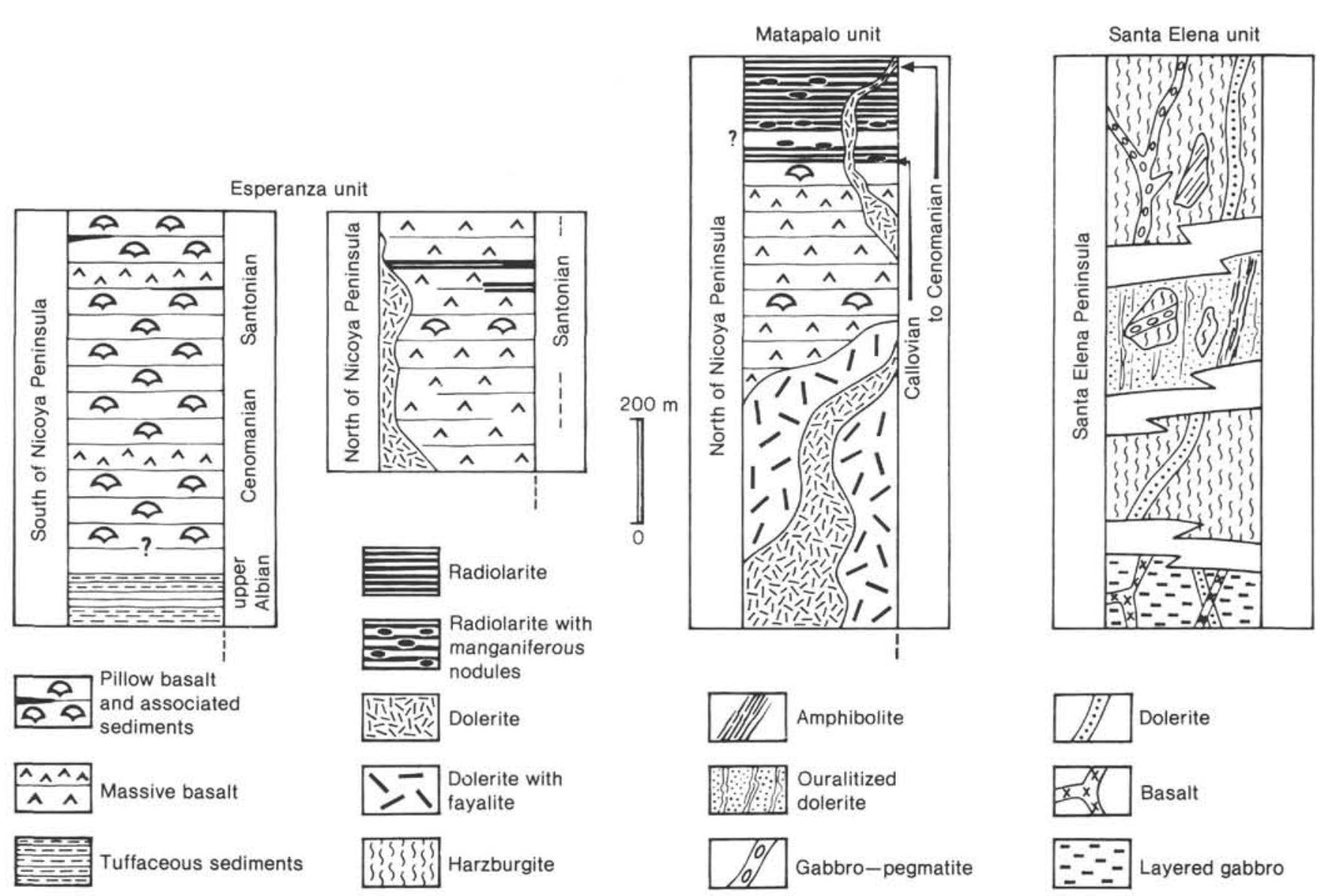

Figure 2. Lithostratigraphic columns of Nicoya Complex units.

The tectonic deformation of the Esperanza unit consists of open folds. On southern Nicoya Peninsula the dips are as great as $25^{\circ}$. Steeper dips are rare and are associated with faults. Northward the deformation involves more closed folds. The deformation, however, of radiolarites and basalt flows (Fig. 3) is always less important in the Esperanza unit than in the Matapalo unit.

\section{The Matapalo Unit}

The Matapalo unit (Kuijpers, 1980) consists of hundreds of meters of gabbro, dolerite, and basalt overlain by a series of radiolarites whose thickness is very difficult to estimate because of intense folding. The Matapalo unit crops out mainly in the northwestern part of Nicoya Peninsula (Fig. 4).

The Matapalo unit radiolarite is generally strongly impregnated with hematite (Kuijpers, 1980), and at a few localities radiolarite contains manganiferous nodules (Fig. 2), as, for example, at El Frances (Fig. 4). Kuijpers and Denyer (1979) have shown that nodules and lenses originate from hydrothermal solutions emanating from the ocean floor. All these features are associated with an overall orange color that is quite different from that of the Esperanza unit radiolarite. The basalts are mainly massive basaltic flows; pillow basalt is rare. Chemical analyses show low $\mathrm{K} / \mathrm{Na}$ ratios. The basalts are made up mainly of clinopyroxene and calcic plagioclase. Magnetite is abundant and the Fe content is very high (see Table 1, column 5). In the Ocotal region (see Fig. 4), a dolerite stock intrudes basalts. The dolerite is composed of labradorite, zoned clinopyroxene (augite to ferroaugite), magnetite, and ilmenite. This dolerite has a very high total iron content of up to $15 \%$ (Table 1, column 6). Differentiated igneous facies of dolerite occur in the Ocotal stock. It is a dolerite with a very high $\mathrm{Fe}$ content, making it a ferrodolerite with fayalite. The $\mathrm{FeO}$ content is as high as $26.5 \%$ in this rock type (Table 1, column 7). A granophyre also occurs (Table 1 , column 8 ) that includes hedenbergite. This rock appears as the final differentiated facies of the Ocotal stock. The mineralogic and chemical compositions of the granophyre of the Ocotal stock are very similar to those of differentiated facies of Skaergaard (Wager and Brown, 1968).

In the Brasilito area radiolarian assemblages of Late Jurassic age (Galli, 1977) and Late Jurassic-Neocomian age (Schmidt-Effing, 1979) were first described. Later a Berriasian-Aptian age was identified for the Matapalo unit (Kuijpers, 1980). Baumgartner (personal communication, 1983) gives new radiolarian ages for various localities in the Matapalo unit. The present data indicate ages from Callovian to Cenomanian. Thus, the basaltic basement of the Matapalo unit dates back to at least Late Jurassic.

Intense isoclinal folding characterizes the Matapalo unit. The deformation is particularly obvious in the ra- 
Table 1. Selected geochemical analyses (wt.\%) of dolerite and basalt of the Santa Elena, Matapalo, and Esperanza units.

\begin{tabular}{|c|c|c|c|c|c|c|c|c|c|c|c|}
\hline & \multirow{2}{*}{\multicolumn{2}{|c|}{$\begin{array}{c}\text { Santa Elena } \\
\text { unit }\end{array}$}} & \multicolumn{9}{|c|}{ Nicoya Complex } \\
\hline & & & \multirow[b]{2}{*}{3} & \multirow[b]{2}{*}{4} & \multicolumn{5}{|c|}{ Matapalo unit } & \multicolumn{2}{|c|}{ Esperanza unit } \\
\hline & 1 & 2 & & & 5 & 6 & 7 & 8 & 9 & 10 & 11 \\
\hline $\mathrm{SiO}_{2}$ & 51.59 & 47.75 & 42.27 & 47.27 & 47.17 & 47.03 & 46.60 & 60.92 & 47.52 & 47.08 & 47.98 \\
\hline $\mathrm{Al}_{2} \mathrm{O}_{3}$ & 14.55 & 14.41 & 12.99 & 13.26 & 11.70 & 13.74 & 11.91 & 11.14 & 15.21 & 16.82 & 14.60 \\
\hline $\mathrm{Fe}_{2} \mathrm{O}_{3}$ & 1.68 & 2.39 & 9.01 & 6.03 & 7.67 & 4.88 & 5.95 & 2.09 & 3.47 & 3.07 & 3.55 \\
\hline $\mathrm{FeO}$ & 7.70 & 6.20 & 4.69 & 9.18 & 9.27 & 10.63 & 20.57 & 9.00 & 5.90 & 4.66 & 7.43 \\
\hline $\mathrm{MnO}$ & 0.17 & 0.15 & 0.20 & 0.22 & 0.25 & 0.09 & 0.27 & 0.13 & 0.11 & 0.10 & 0.19 \\
\hline $\mathrm{MgO}$ & 6.15 & 9.42 & 6.85 & 6.27 & 5.81 & 5.14 & 0.97 & 1.01 & 8.53 & 8.36 & 8.25 \\
\hline $\mathrm{CaO}$ & 11.57 & 8.77 & 11.50 & 9.60 & 9.08 & 9.71 & 5.95 & 7.18 & 13.07 & 14.36 & 11.66 \\
\hline $\mathrm{Na}_{2} \mathrm{O}$ & 2.95 & 3.66 & 1.81 & 2.44 & 2.32 & 3.23 & 2.57 & 4.21 & 1.64 & 1.49 & 2.06 \\
\hline $\mathrm{K}_{2} \mathrm{O}$ & 0.11 & 0.16 & 2.66 & 0.38 & 0.56 & 0.18 & 0.24 & 0.54 & 0.25 & 0.04 & 0.29 \\
\hline $\mathrm{TiO}_{2}$ & 1.16 & 0.60 & 3.25 & 1.29 & 2.56 & 1.90 & 1.55 & 2.28 & 0.75 & 0.79 & 1.00 \\
\hline $\mathrm{P}_{2} \mathrm{O}_{5}$ & 0.10 & 0.06 & 0.41 & 0.10 & 0.21 & trace & 0.17 & 0.27 & 0.31 & trace & 0.06 \\
\hline $\mathrm{H}_{2} \mathrm{O}+$ & 1.99 & 5.12 & 2.24 & 0.44 & - & 2.89 & 1.65 & 0.63 & 1.87 & 2.93 & 2.54 \\
\hline $\mathrm{H}_{2} \mathrm{O}^{-}$ & trace & 0.62 & 1.03 & 1.79 & 3.81 & 1.01 & 0.91 & 0.41 & 0.57 & 0.46 & 0.92 \\
\hline Total & 99.82 & 99.31 & 98.91 & 99.30 & 100.41 & 100.43 & 99.31 & 99.81 & 99.20 & 100.16 & 100.53 \\
\hline Q & 1.95 & - & - & 3.73 & 6.01 & - & 4.86 & 18.35 & 0.37 & - & - \\
\hline Or & 0.67 & 0.94 & 15.73 & 2.22 & 3.28 & 1.06 & 1.39 & 3.17 & 1.44 & 0.22 & 1.72 \\
\hline $\mathrm{Ab}$ & 24.94 & 30.92 & 8.17 & 20.59 & 19.60 & 27.30 & 21.69 & 35.58 & 13.83 & 12.57 & 17.40 \\
\hline An & 26.08 & 22.41 & 19.40 & 24.10 & 19.85 & 22.43 & 20.27 & 9.90 & 33.39 & 39.06 & 29.69 \\
\hline $\mathrm{Ne}$ & - & - & 3.86 & - & - & - & - & - & - & - & - \\
\hline $\mathrm{Di}$ & 25.12 & 16.65 & 27.19 & 13.36 & 19.25 & 21.28 & 7.18 & 20.77 & 23.59 & 25.59 & 22.44 \\
\hline En & 8.23 & 1.20 & - & 11.71 & 8.21 & 5.50 & 2.14 & 0.55 & 12.80 & 10.27 & 11.83 \\
\hline Fs & 5.97 & 0.45 & - & 7.58 & 3.91 & 5.36 & 27.26 & 2.45 & 4.14 & 2.40 & 5.37 \\
\hline Fo & - & 11.55 & 3.16 & - & - & 1.40 & - & - & - & 0.55 & 0.95 \\
\hline $\mathrm{Fa}$ & - & 4.71 & - & - & - & 1.51 & - & - & - & 0.14 & 0.47 \\
\hline $\mathrm{Ma}$ & 2.43 & 3.46 & 2.02 & 8.75 & 11.11 & 7.08 & 8.61 & 3.04 & 5.03 & 4.45 & 5.15 \\
\hline Il & 2.20 & 1.34 & 4.44 & 2.45 & 4.86 & 3.60 & 2.95 & 4.33 & 1.43 & 1.50 & 1.90 \\
\hline Ap & 0.23 & 0.13 & 2.12 & 0.23 & 0.50 & - & 0.40 & 0.64 & 0.74 & - & 0.13 \\
\hline $\mathrm{He}$ & - & - & 4.08 & - & - & - & - & - & - & - & - \\
\hline
\end{tabular}

Notes: (1-2) sheeted dike complex (Santa Elena peridotite); (3-4) basalts of the volcanosedimentary unit of Santa Elena Peninsula; (5-9) Matapalo unit on northern Nicoya Peninsula; (10) dolerite of the Esperanza unit north of Nicoya Peninsula; (11) Esperanza unit south of Nicoya Peninsula. The Fe content of Matapalo unit samples is very high. $-=$ no significant result.

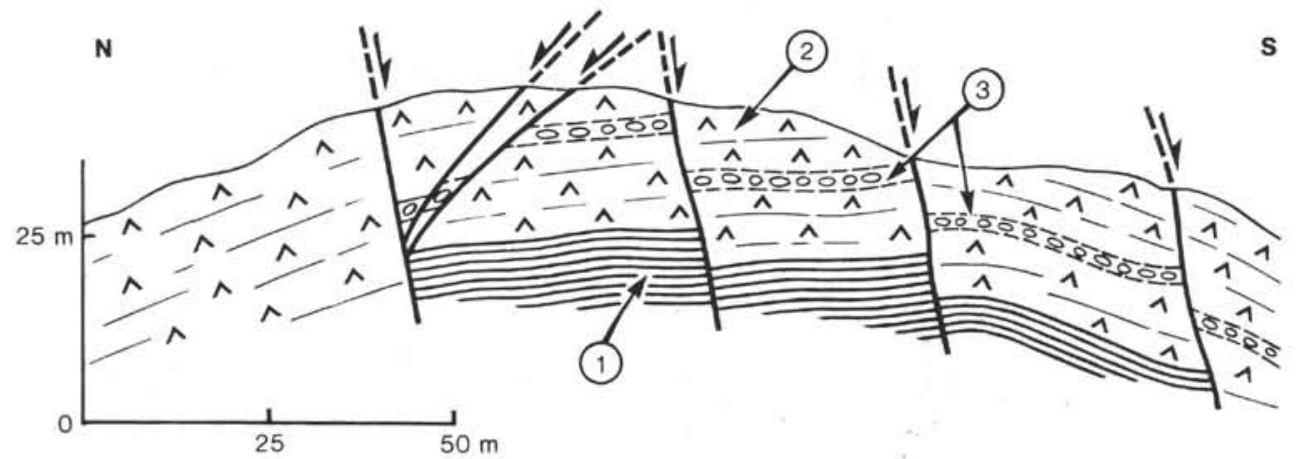

Figure 3. Cross-section of the road cut between Huacas and El Llano (for location, see Fig. 4). (1) Radiolarite; (2) dolerite; (3) dolerite with rounded feldspars.

diolarite, and it forms a good criterion to differentiate Matapalo radiolarite from Esperanza radiolarite. Small isoclinal folds occur along the basal radiolarite contact (Kuijpers, 1980). It is evident that the basalt was also affected by the same episode of folding. However, slumping is also obvious in the radiolarite in exposures south of Huacas. The importance of the isoclinal folding has been overestimated in some previous studies (de Boer, 1979; Kuijpers, 1980) because a distinction has not been made between tectonic and synsedimentary folds.
The distinguishing characteristics of the Matapalo unit are (1) a Callovian-Cenomanian age; (2) a basaltic and doleritic basement with a very high Fe content; (3) intense isoclinal folding; and (4) an apparent oceanic paleoenvironment (radiolarites with manganiferous nodules). In contrast, none of these features occur in the Esperanza unit, which is instead characterized by (1) an Albian-Santonian age; (2) a basaltic and doleritic basement with a low Fe content; and (3) less folding than in the Matapalo unit. 

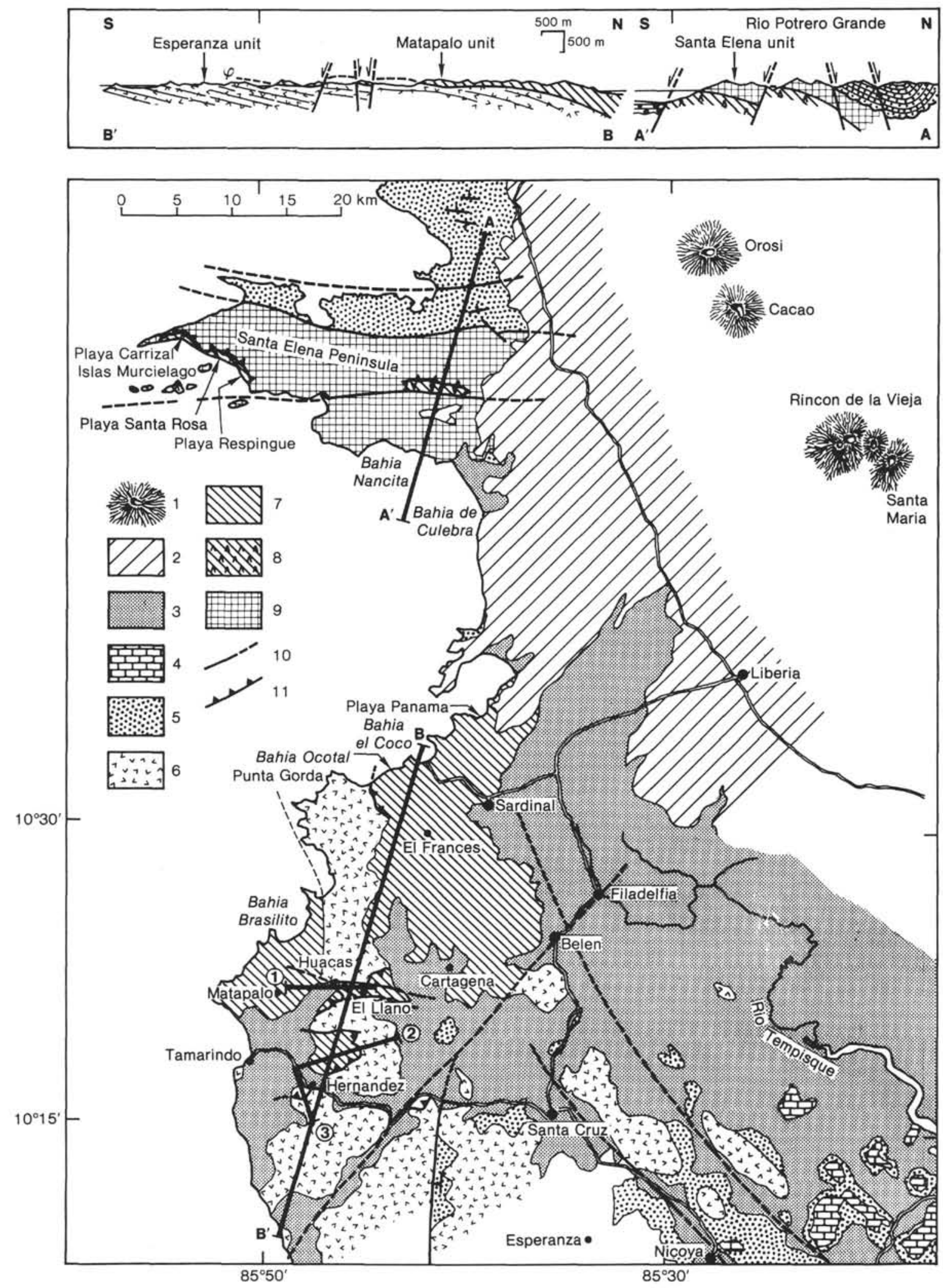

Figure 4. Geologic sketch map of Santa Elena and Nicoya peninsulas and generalized cross-section (top). (1) Volcanoes; (2) ignimbrite; (3) alluvium; (4) Barra Honda Formation; (5) Sabana Grande-El Viejo, Rivas, and Las Palmas formations (Upper Cretaceous-Paleocene); (6) Esperanza unit (Albian-Santonian); (7) Matapalo unit (Callovian-Cenomanian); (8) volcanosedimentary unit of the Santa Elena Peninsula; (9) Santa Elena unit (peridotite); (10) faults; (11) overthrusts. Circled numbers (1), (2), and (3) show locations of cross-sections shown in Figure 5. 
The Volcanic and Sedimentary Material of the Santa Elena Peninsula

Volcanic and sedimentary material occurs in some tectonic windows beneath the peridotites of the Santa Elena Peninsula (Azéma and Tournon, 1980; Tournon and Azéma, 1980). This material consists mainly of pillow basalts and radiolarites that locally contain radiolarian assemblages of Cenomanian (Schmidt-Effing, 1980) and Albian-Cenomanian age (Azéma et al., 1982). These formations probably belong to a northern equivalent of the Nicoya Complex. Indeed, the volcanic rocks have affinities with those of the Matapalo unit (see Table 1, columns 3 and 4), whereas some of radiolarites contain the same facies as the radiolarites of the Esperanza unit. Moreover, there are some differences between the volcanic and sedimentary material of the tectonic windows and the Matapalo and Esperanza unit material. On the Santa Elena Peninsula there is also siliceous limestone of Albian age and radiolarite breccia that contains radiolarian assemblages of Albian-Cenomanian age with reworked radiolarians of Late Jurassic and Neocomian ages (De Wever, personal communication, 1983).

\section{The Santa Elena Unit}

Mafic and ultramafic rocks differing from the Esperanza and Matapalo units crop out in the Santa Elena Peninsula (Fig. 2). They were first noted by Harrison (1953) and later described by Dengo (1962a, b). Petrographic and geochemical studies were recently made by Tournon and Azéma (1980). The major component of the massif is serpentinized harzburgites. Layered gabbros also crop out at Bahia Nancite (Fig. 4). The relationship between the harzburgite and the cumulates is not yet known. A doleritic and basaltic sheeted dike complex cuts into the stratified mafic rocks and another sheeted dike complex (Table 1, columns 1,2) composed of pegmatitic gabbros also cuts into the ultramafic rocks. Within the peridotite foliated amphibolite and pyroxenite occur as blocks and shear zones. These rocks are fragments of an ophiolitic complex (Dengo, 1962a, b; Weyl, 1969; Schmidt-Effing, 1980; Azéma and Tournon, 1980; Tournon and Azéma, 1980). The ophiolitic sequence has a mineralogy and geochemistry similar to the basement rocks drilled during Leg 84 (Bourgois et al., this volume).

\section{The Nicoya Complex Megastructures}

The emplacement of nappes along the Costa Rican Pacific coast was proposed originally in two papers. (1) Azéma and Tournon (1980) proposed that the allochthon of the Santa Elena peridotite rests on radiolarites exposed in the Rio Potrero Grande window on central Santa Elena Peninsula. (2) Kuijpers (1980) proposed that an allochthon for the younger Esperanza unit rests on top of the older Matapalo unit on northwestern Nicoya Peninsula.

\section{The Overthrust of the Matapalo Unit}

The lithostratigraphy of the Matapalo unit is characterized by radiolarites that differ from those of the Esperanza unit by their facies, age, and nature of folding.
In the Matapalo-Cartagena area, Matapalo radiolarite intruded by dolerites is common (Fig. 2). Mapping shows that the radiolarite of the Matapalo unit rests structurally on the basalt and the interbedded radiolarite of the Esperanza unit (Fig. 4). The structural relationship of these two units is also well exposed in the Huacas-El Llano region. A cross-section based on road cuts between Huacas and El Llanos (Fig. 3) shows very gently dipping radiolarite beds. Dips are southward to the south, northward to the north, and outline a very open fold. The southern limb of this anticline dips under the older and more folded radiolarite of the Matapalo unit, as shown on the cross-sections of Fig. 5. Such mapping shows that the Matapalo unit is a tectonic slice thrust on top of the Esperanza unit.

\section{The Overthrust of the Santa Elena Unit}

The Rio Potrero Grande window and the related overthrusts of Playa Carrizal and Playa Respingue have been described by Azéma and Tournon (1980, 1982). Mafic and ultramafic rocks of the Santa Elena unit (Fig. 4) rest structurally on folded radiolarite of Rio Potrero Grande and the volcaniclastic sediments of Playa Carrizal and Playa Respingue. The tectonic contact consists of a thick tectonic breccia, which is well exposed at Playa Carrizal and Playa Respingue, and is accompanied by intense folding. Isoclinal folds are obvious, particularly in the lower part of the overthrusted peridotites. Vergence of the folds indicates that emplacement of the Santa Elena nappe was from north to south, which is in agreement with the general east-west trend of the pre-upper Senonian structures. In addition, Albian-Cenomanian radiolarian assemblages were documented in the sediments underlying the Santa Elena peridotite (Schmidt-Effing, 1980; Azéma et al., 1982).

\section{Conclusion}

The most important tectonic feature of the pre-upper Senonian rocks of the Nicoya Complex is the large Santa Elena and Matapalo nappes. Nappe emplacement was apparently from north to south. These major structural features are considered to be products of post-late Santonian tectonic stress (Kuijpers, 1980) for the lowest Esperanza unit contains Santonian radiolarite and is unconformably overlain by Campanian-Maestrichtian rocks.

\section{THE SEDIMENTARY COVER: CAMPANIAN- TERTIARY ONSHORE HISTORY}

\section{Sabana Grande and El Viejo Formations}

The Sabana Grande Formation (Fig. 6) (McDonald, 1920; Dengo, 1962a, b) is a lithologically heterogeneous sequence that overlies dolerites, basalts, and radiolarites of the Nicoya Complex. Sabana Grande limestones are late Campanian and Maestrichtian in age (Galli and Schmidt-Effing, 1977; Azéma and Tournon, 1980), and the lowermost base of the overlying Rivas Formation is early Paleocene in age. The most complete section of the Sabana Grande Formation (Fig. 7A) has a thickness of 250 $\mathrm{m}$ and crops out in the southeastern part of Nicoya Peninsula. The best outcrops are along the coast from 

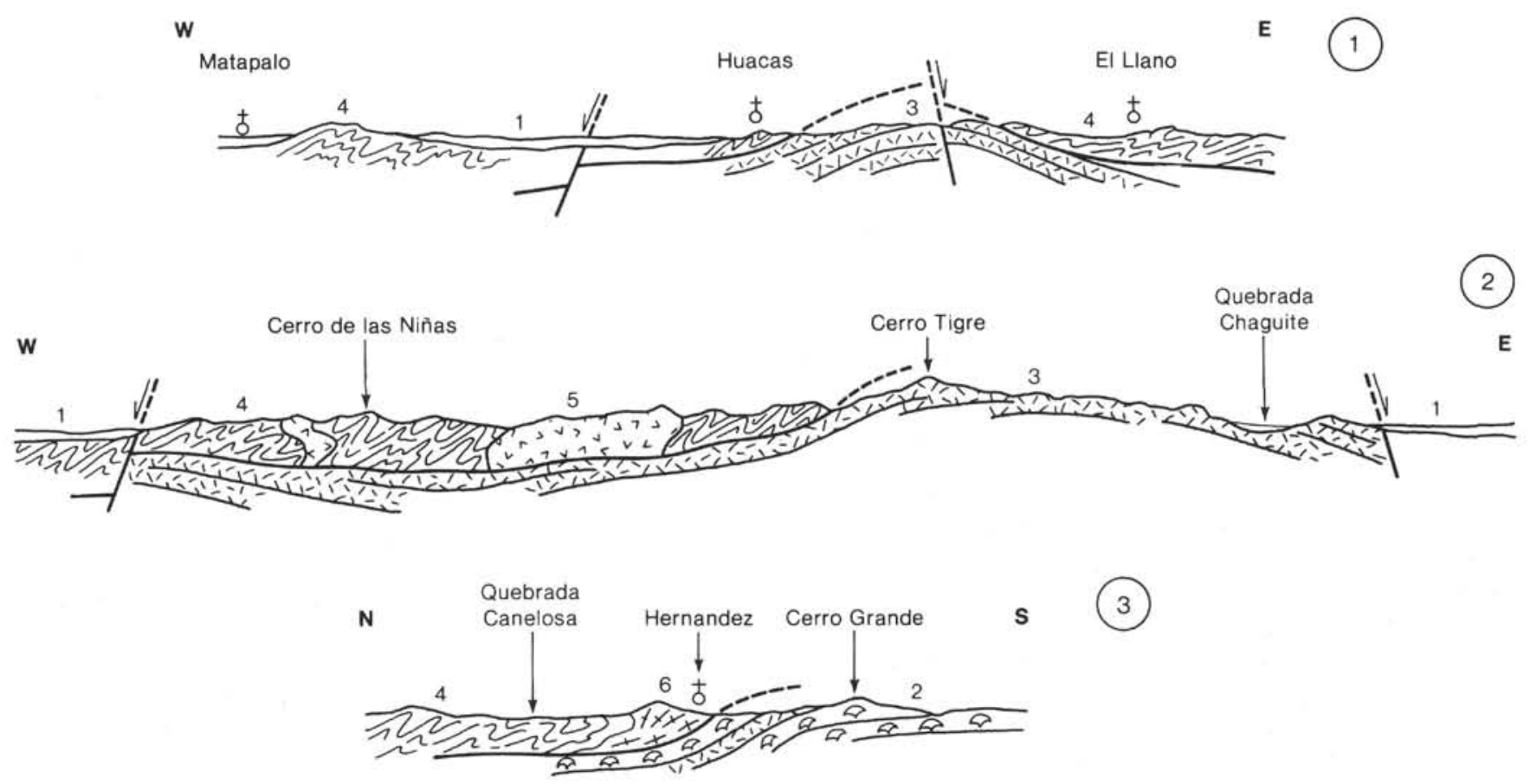

Figure 5. Three cross-sections through the Matapalo unit overthrust (for location of cross-sections, see Fig. 4). (1) alluvium; (2) Esperanza unit pillow basalt; (3) Esperanza unit basalt massive flow; (4) Matapalo unit isoclinal folded radiolarite; (5) Matapalo unit dolerite; (6) Matapalo unit granophyre.

Montezuma in the southwest to Playa Curù in the northeast.

In the Montezuma and Playa Curù regions (Fig. 7A), the base of the Sabana Grande Formation is a thick sedimentary breccia that was interpreted to be the uppermost Nicoya Complex by Lundberg (1982). The clasts or blocks range in size from 1 to $100 \mathrm{~cm}$ and greater and originate from the underlying Nicoya Complex; they are composed of dolerite, basalt, radiolarite, and jasper. At Playa Curù the sedimentary breccia lies on pillow basalts of the Nicoya Complex that dip more steeply than those at Montezuma. Interbedded in sedimentary breccias are thinly bedded turbidites of fine-grained volcanic debris and siliceous mudstone of the Sabana Grande Formation. In some places, the breccia matrix is a red siliceous mudstone. Apparently the breccia that overlies the Nicoya Complex is the basal sedimentary breccia of the Sabana Grande Formation. The sediment associated with the breccia appears to be from a deep-water environment, as is the underlying Nicoya Complex and the overlying part of the Sabana Grande Formation (Lundberg, 1982).

In the southern part of Nicoya Peninsula, the sedimentary breccias are overlain by siliceous mudstones interbedded with very thinly bedded volcanogenic turbidites. Volcanic ash layers are commonly 10 to $15 \mathrm{~cm}$ thick; the whole sequence is 150 to $180 \mathrm{~m}$ thick. The depositional environment was probably a very distal deep-sea fan. On top of this lies a pink to white limestone rich in planktonic foraminifer tests. The limestone is medium to thinly bedded and up to $50 \mathrm{~m}$ thick. It gives way upward in the section to pink and white calcareous mudstone that is overlain by a $25-\mathrm{cm}$-thick ash layer at the very top. The limestone and calcareous mudstone most likely represent deep-water deposits that accumulated above the local calcite compensation depth (CCD) and that were composed largely of calcareous nannoplankton and foraminifer tests. The Sabana Grande Formation, including the basal conglomerate and the topmost calcareous mudstones, apparently originated in a deepwater environment.

In the southern part of Santa Elena Peninsula in the Rio Nisperal area (Fig. 7C), the peridotite is directly overlain by the El Viejo Limestone (name proposed by Schmidt-Effing, 1975). The basal unconformity is documented by a conglomerate consisting of subrounded peridotite pebbles. There are no radiolarite or basalt clasts. The limestone is largely composed of rudistids, nerineas, and corals and also contains large benthic foraminifers. Above this lies a pink to white, medium to thinly bedded calcareous mudstone that compares to the upper calcareous portion of the more southerly Sabana Grande Formation; the whole section is a maximum of $60 \mathrm{~m}$ thick. In this region the deep-water siliceous part of the Sabana Grande Formation is apparently replaced by the reefal El Viejo Formation. The lower part of the Senonian section here is of shallow-water origin (Fig. 7B). On northern Santa Elena Peninsula in the Hacienda Murcielago region, the contact between the peridotites and the El Viejo Limestone is faulted. However, reworked peridotite pebbles in the basal part of the shallow-water limestone section suggest the same relationships as in southern and central Santa Elena Peninsula. Along the fault zone, deep-water calcareous mudstone containing Globotruncana appears to be intercalated with shallow water 


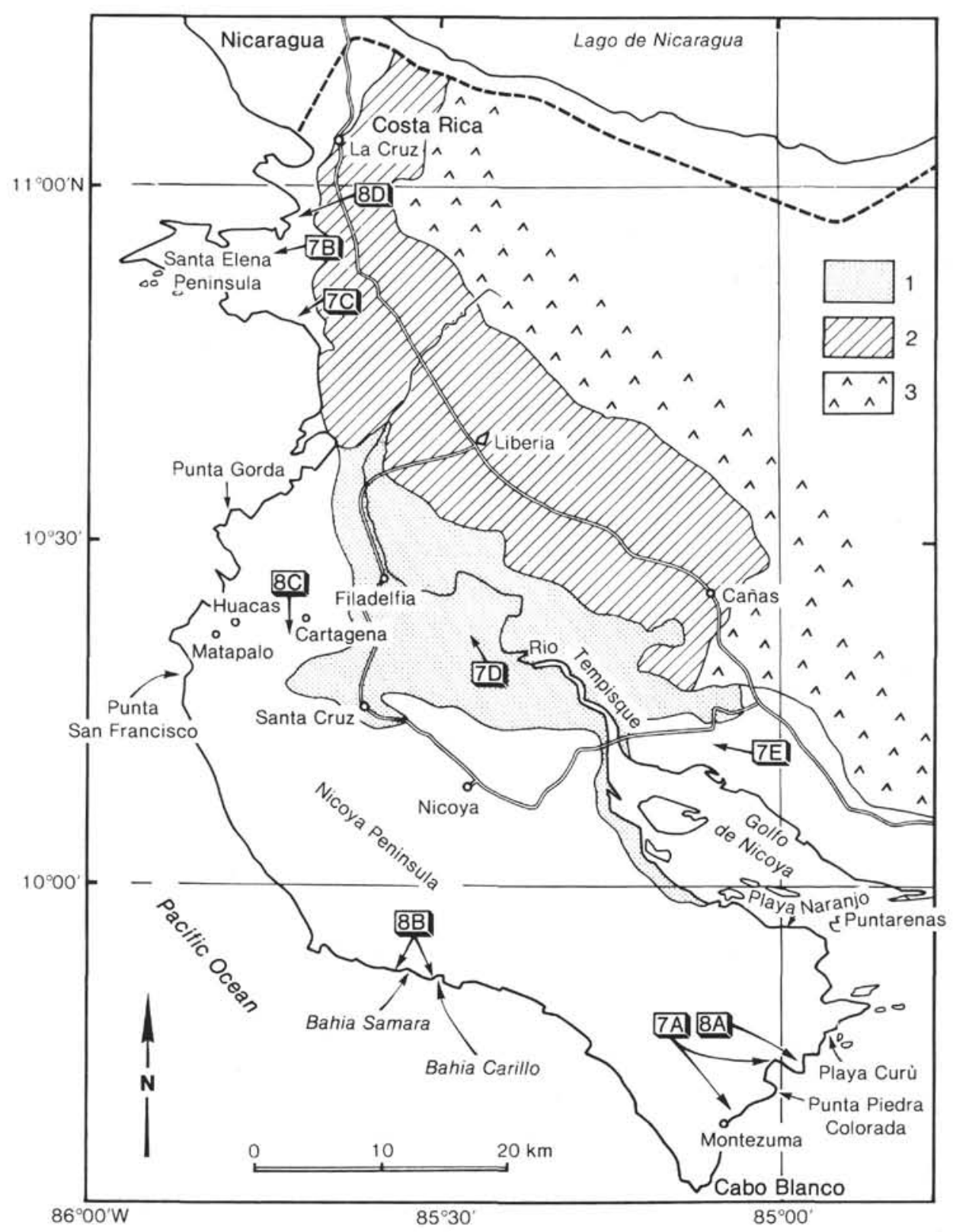

Figure 6. Locations (shown in boxes) of the generalized columns described in Figure 7 (Sabana Grande Formation) and Figure 8 (Paleocene sediments). (1) Alluvium, (2) ignimbrite; (3) Pleistocene volcanism.

limestone. Another shallow-water section of El Viejo Limestone crops out near Bolson southeast of Filadelfia in the Rio Tempisque depression (Fig. 7D).

North of the Gulf of Nicoya (Fig. 7E) near Colorado de Abangares, Rivier (1983) describes a possibly continental conglomerate (Conglomerado Barbudal) that resulted from the erosion of the Nicoya Complex. The conglomerate is composed of basalt, dolerie, gabbro, and red radiolarite pebbles "floating" in a red muddy matrix, which strongly suggests a terrestrial origin. The red conglomerate is overlain by a yellow, much more winnowed, possibly marine conglomerate containing wellrounded pebbles, which in turn gives way upward in the section to fine-grained sandstones with clasts of reworked shallow-water material, bioclastic limestones, and finally calcareous mudstones that closely resemble the calcare- ous upper member of the Sabana Grande Formation and that are also of Campanian-Maestrichtian age.

Thus a lithostratigraphic study of the Sabana Grande and El Viejo formations on Santa Elena and Nicoya peninsulas reveals a prominent unconformity at their base. This unconformity is at the base of sediments of terrestrial or shallow-water origin on Santa Elena Peninsula and in the Rio Tempisque regions and of deep-water origin on southern Nicoya Peninsula. This lithologically heterogeneous unit is late Campanian-Maestrichtian in age.

Paleogene Sequences on Nicoya Peninsula: Rivas, Las Palmas, and Samara Formations

On Nicoya and Santa Elena peninsulas, the Sabana and El Viejo formations are overlain by clastic turbidite beds ranging in age from Late Cretaceous to Paleocene 


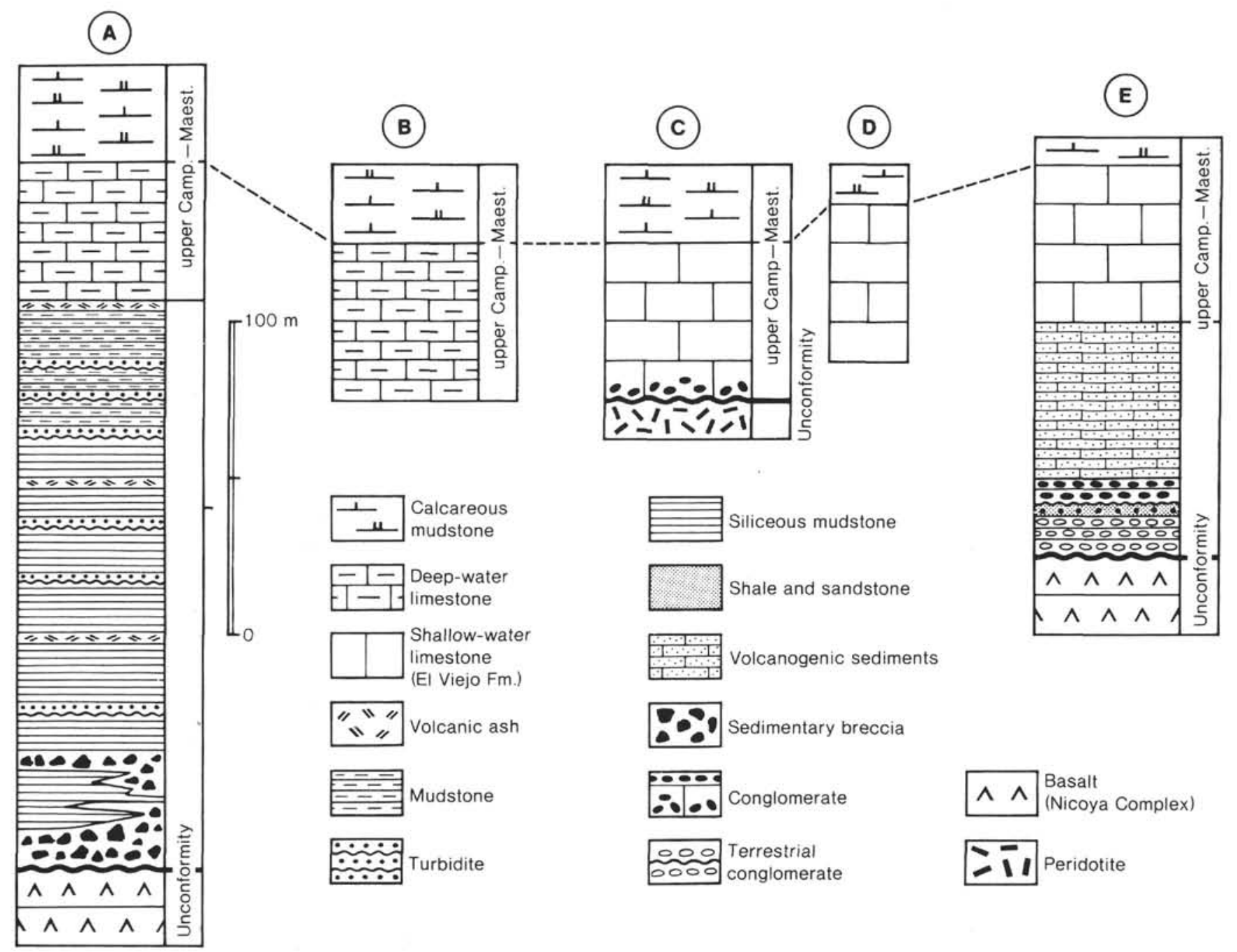

Figure 7. Lithostratigraphic columns of the Sabana Grande and El Viejo formations. (A) Montezuma-Curù zone; (B) north of the Santa Elena Peninsula; (C) south of the Santa Elena Peninsula; (D) Bolson; (E) north of Golfo de Nicoya. (For locations, see Fig. 6.)

(Harrison, 1953; Lexique Stratigraphique International, 1960; Dengo, 1962a; Galli and Schmidt-Effing, 1977; Azéma et al., 1981). Some authors proposed that the Las Palmas Formation includes the lower Eocene deposits (Dengo, 1962a; Kuijpers, 1980; Lundberg, 1982).

The Rivas and Las Palmas formations are well exposed along the coast from Montezuma to Playa Naranjo. The Paleocene sequence is composed of clastic turbidites up to $1500 \mathrm{~m}$ thick. The Rivas and Las Palmas formations are divided into three subunits in this study (Fig. $8 \mathrm{~A})$. At the base is the shaly subunit. Its contact with the underlying Sabana Grande Formation is well exposed north of Punta Piedra Colorada. The contact is sharp and is underlined by a $25-\mathrm{cm}$-thick ash layer at the very top of the pink lutitic limestone of the Sabana Grande Formation. The shaly subunit containing thinly bedded turbidites grades upward through a more sand-rich sequence to thickly bedded turbidites. The shaly subunit is a maximum of $500 \mathrm{~m}$ thick. According to Lundberg (1982) it probably represents distal turbidites, whereas the sandy, coarsening-üpward beds could represent part of a midfan environment.
The thickly bedded turbidites of the shaly subunit are overlain by a massive sandstone subunit that contains turbidite beds up to $15 \mathrm{~m}$ thick. According to Lundberg (1982), this unit represents channel fill and interchannel deposits that give way upward to thin beds deposited in a midfan environment. The sandstone subsequence is 600 $m$ thick.

Volcanogenic detritus is abundant in the upper carbonate subunit as in the two lower subunits (Fig. 8A). The turbidites of this sequence, however, are rich in carbonate lithic detritus reflecting reworking of shallow-water sediments. The upper carbonate subunit is approximately equivalent to the Las Palmas. Formation (Gardner in Dengo, 1962a; Lundberg, 1982) and is a maximum of $500 \mathrm{~m}$ thick. It is dominated by thinly bedded turbidites that locally include thickly bedded carbonate conglomerates and sandstones. The upper carbonate subunit is well exposed near Playa Naranjo, in particular at the Puntarenas ferryboat terminal. The Rivas and Las Palmas formations also crop out in the vicinity of Santa Cruz and Nicoya in the middle of Nicoya Peninsula. For example, the thinly bedded turbidites of the shaly sub- 

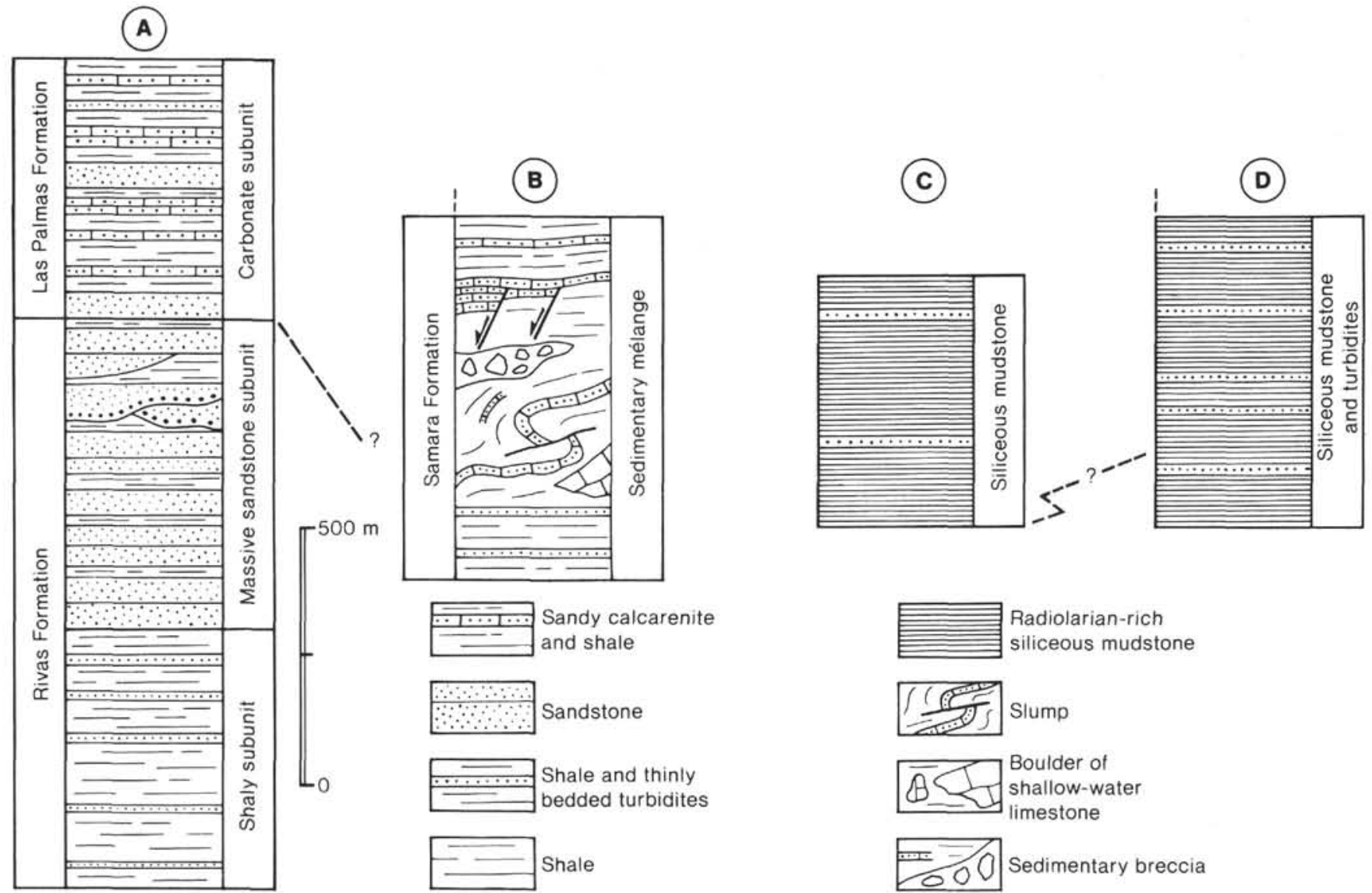

Figure 8. Lithostratigraphic columns of Paleocene sediments on Nicoya and Santa Elena peninsulas. (A) South of Nicoya Peninsula; (B) Samara zone; (C) north of Nicoya Peninsula; (D) north of Santa Elena Peninsula. (For locations, see Fig. 6.)

unit are well exposed along Nicoya-La Mansion road. As at Punta Piedra Colorada, the Rivas Formation exhibits synsedimentary deformation that is usually faulted.

The Samara Formation (Formacion Arenisca Lutita Samara: Sprechmann, 1982) is well exposed south of Nicoya along the cliffs near Bahia Carrillo and Bahia Samara. It consists of olistostromes that include both local and exotic material (Fig. 8B).

The Paleocene sediments are of deep-water origin on northern Nicoya and Santa Elena peninsulas. In the vicinity of Cartagena (Fig. 8C) the sequence is mainly composed to regular, thinly stratified, red siliceous limestone with very thin shaly partings. Beds are 8 to $10 \mathrm{~cm}$ thick, and the sediment is rich in radiolarians and contains sparse graded bedding and cross-lamination. The estimated thickness is at least several hundred meters. In the Cuajiniquil region (Figs. 6 and 8D) on northern Santa Elena Peninsula, Paleocene sediments are composed of radiolarian-rich, siliceous mudstones interbedded with very thinly bedded volcaniclastic turbidites. The most complete section has a minimum thickness of $500 \mathrm{~m}$. Thus the Paleocene sediments of the Nicoya and Santa Elena peninsulas were deposited in a variety of sedimentary environments as during Late Cretaceous time. On southeastern Nicoya Peninsula, Paleocene deposits mostly originated in a deep-water, midfan environment; in the northern regions they are of deep-water origin.

\section{Barra Honda Formation}

The Barra Honda Formation is a shallow-water limestone occurring in patches of highly variable thickness (maximum $250 \mathrm{~m}$ ), overlying Upper Cretaceous-lower Eocene deep-water formations with a prominent unconformity (Rivier, 1983). Algal micrites prevail in the lower massive portion, whereas bioclastic limestones constitute the upper, thickly stratified part of the formation. Its age was considered to be Paleocene by Dengo (1962a); however, Mora (1978 and 1981) and Kuijpers (1980) point out that the Barra Honda Formation must be much younger. Rivier (1983) states that its age must be younger than early Eocene and concludes, from the absence of the otherwise common large foraminifers, a post-Oligocene or possibly even Miocene age.

\section{Conclusion}

On northern Nicoya and Santa Elena peninsulas, the upper Campanian-Maestrichtian sediments of the El Viejo Formation are apparently of shallow-water origin. Except in North Santa Elena, the sediments of the coeval Sabana Grande Formation originated in deep water above the CCD. The Paleocene sediments of the Rivas, Las Palmas, and Samara formations formed in a deepwater, clastic environment. Late Eocene-Oligocene(?) time marked a change in the sedimentary environment from 
predominantly deep water to shallow water (Barra Honda Formation).

Two unconformities are prominent geologic features of the post-Late Cretaceous history of the Nicoya and Santa Elena peninsulas. The lower one is prominent because the pre-late Campanian rocks are tectonically deformed (folds, overthrusts, and nappes), whereas the younger rocks are less deformed. In addition, the prelate Campanian geologic history is recorded in ophiolitic rocks of a primitive island arc involving oceanic crust, whereas post-late Campanian history involves sediment of a continental margin. The upper unconformity is not as prominent as the lower one.

\section{OFFSHORE CAMPANIAN-TERTIARY SEQUENCES}

\section{Middle America Trench Off Costa Rica}

Multifold seismic reflection data taken off the west coast of Costa Rica were collected by the University of Texas Institute for Geophysics (Shipley et al., 1982; Crowe and Buffler, unpublished; Buffler, unpublished). Data were taken along 7 lines perpendicular to the Trench axis that extend across the subducted Cocos Plate and the landward Trench slope (Fig. 9) and along 3 lines parallel to the Nicoya Peninsula coast. Records taken seaward of the Trench show a 500-m-thick sedimentary sequence overlying acoustic basement (Fig. 10), which is inferred to represent the top of igneous oceanic crust. As off Gua- temala, all records show the Cocos Plate entering the Trench and show a continuation of oceanic crust beneath the Costa Rican Slope for as much as $60 \mathrm{~km}$ (Fig. 10). On the slope itself, the most prominent recorded feature is the strong reflector representing a discontinuity that extends from the Trench to the continental shelf. It defines a boundary between discontinuous reflections and diffractions below and a well-layered section of sedimentary rock above. Thus the University of Texas seismic records define the basement of the Costa Rican slope. In cross-section it is a wedge between the strong reflectors of the subducted oceanic crust and the slope deposits. It is designated as the slope basement wedge (SBW; Fig. 10). The relatively high acoustic velocity in this zone (3.6$5.0 \mathrm{~km} / \mathrm{s}$ ) suggests that it is indurated sedimentary rock or volcanic rock.

\section{Middle America Trench Off Guatemala}

The Middle America Trench off Guatemala is one of the best studied trenches in the world (Aubouin et al., 1979; von Huene, Aubouin et al., 1980; Aubouin, von Huene, et al., 1982a, b). It is the only trench beneath which the igneous ocean crust has been sampled (Sites 499 and 500 of Leg 67) (Fig. 11), and its landward slope is the only one where basement cores of the slope have been recovered (Sites 566, 567, 569, and 570 of Leg 84) (Fig. 11). The Middle America Trench off Guatemala was surveyed by Seabeam (Aubouin, Stephan, et al., 1982), multichannel reflection seismics (Ladd et al., 1982), and

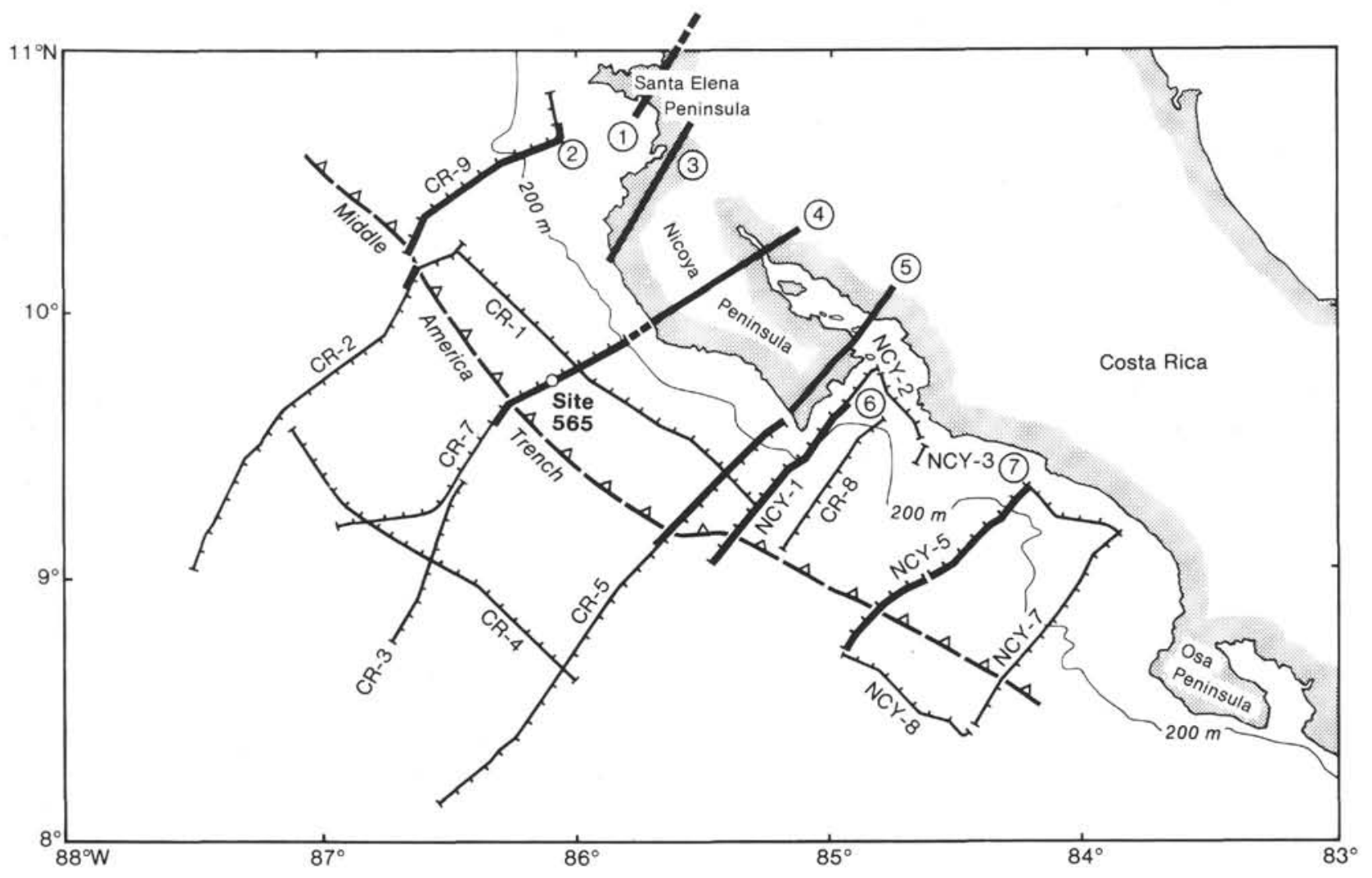

Figure 9. Location of seven multifold seismic lines, shown in Figure 10, taken by the University of Texas Institute for Geophysics. (Modified after Crowe and Buffler, unpublished; Buffler, unpublished.) 


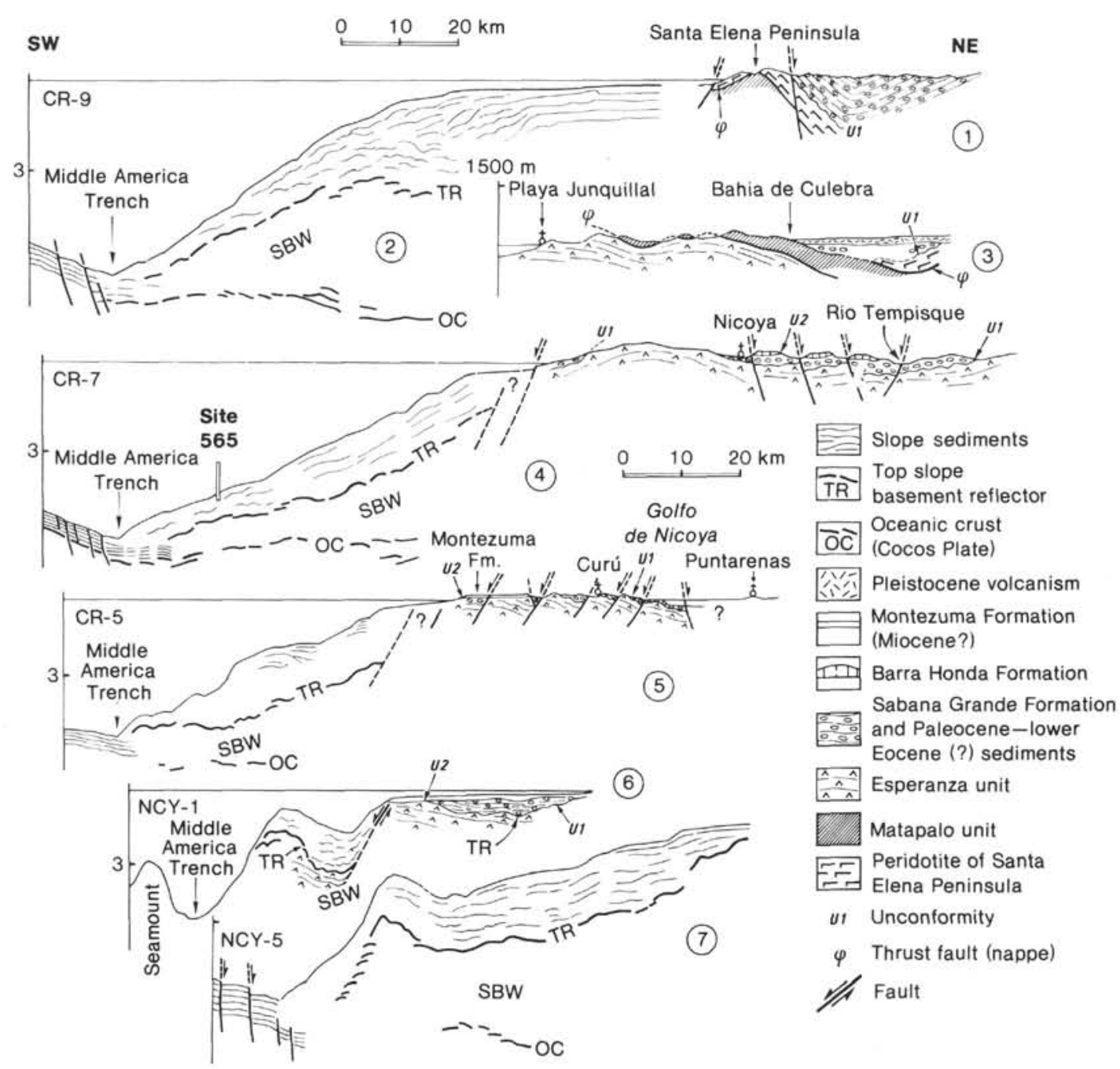

Figure 10. Seven generalized profiles from Middle America Trench to Santa Elena and Nicoya peninsulas. Locations shown in Figure 9. SBW = slope basement wedge. (Offshore data from Buffler, unpublished; Crowe and Buffler, unpublished.)

deep tow (Moore et al., 1982). The preliminary results of these studies show that although the Cocos Plate sinks into a subduction zone, no evidence of accretion has been found. All the material on the oceanic Cocos Plate is being subducted under the continental slope. This contrasts with the earlier interpretations of the seismic reflection records across the landward slope of the Trench (Seeley et al., 1974). The base of the slope deposits (Fig. 12) produces a strong reflector because of the difference in seismic velocities across it. The slope sediment has an average velocity of $2.2 \mathrm{~km} / \mathrm{s}$, whereas the underlying basement has a velocity of 3.2 to $5.5 \mathrm{~km} / \mathrm{s}$ (Ladd et al., 1982). Although not always clearly displayed, the contact is locally a clear unconformity (von Huene et al., 1982), with stratified sediment resting on a generally nonstratified unit. Where the unconformity was penetrated by drilling, it consists of bedded sediment on an igneous complex (Aubouin, von Huene, et al., 1982a, b). The thick Paleocene sequence drilled on the outer shelf at the Esso Petrel Well (Seely et al., 1974) was not recovered at the drill sites on the slope.
Whether this absence resulted from nondeposition or from erosion remains questionable. The pre-upper Oligocene unconformity, however, strongly suggests an erosional event. The upper Senonian limestone recovered at Site 567 testifies for a relatively deep-water environment along the lower slope during that time. Unfortunately, it is not possible at this time to give a more detailed account of the Paleocene.

\section{TECTONIC ANALYSIS OF CAMPANIAN- TERTIARY SEDIMENTS: SOME SPECULATIONS}

Onshore on the central part of Nicoya Peninsula in the Rio Tempisque area the sedimentary cover consists mainly of the Barra Honda Formation overlain by Recent sediments and volcanic flows. The dip of the limestone beds is very slight $\left(0-25^{\circ}\right)$. The strike of the bedding is $\mathrm{N} 120^{\circ}$ to $\mathrm{N} 150^{\circ}$; it parallels the regional trend of normal faulting associated with the Rio Tempisque valley (Fig. 13). Normal faulting is not confined to the Rio Tempisque area; it is the characteristic structure 


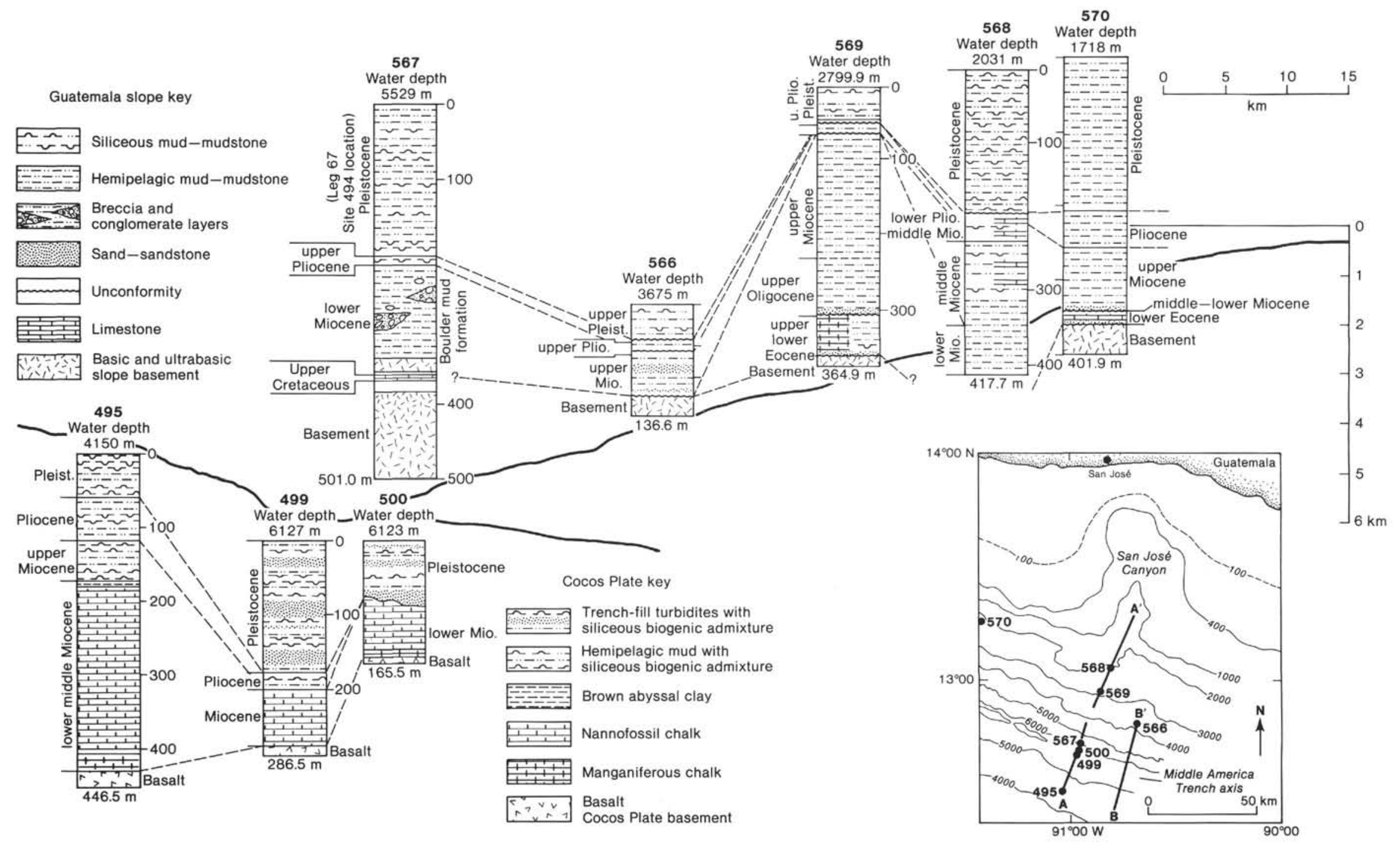

Figure 11. Simplified stratigraphic columns summarizing the lithostratigraphy and biostratigraphy of Legs 67 and 84 drill sites. (After Aubouin, Bourgois, et al., 1982, 1984.) (Bathymetry in meters on inset map.) 


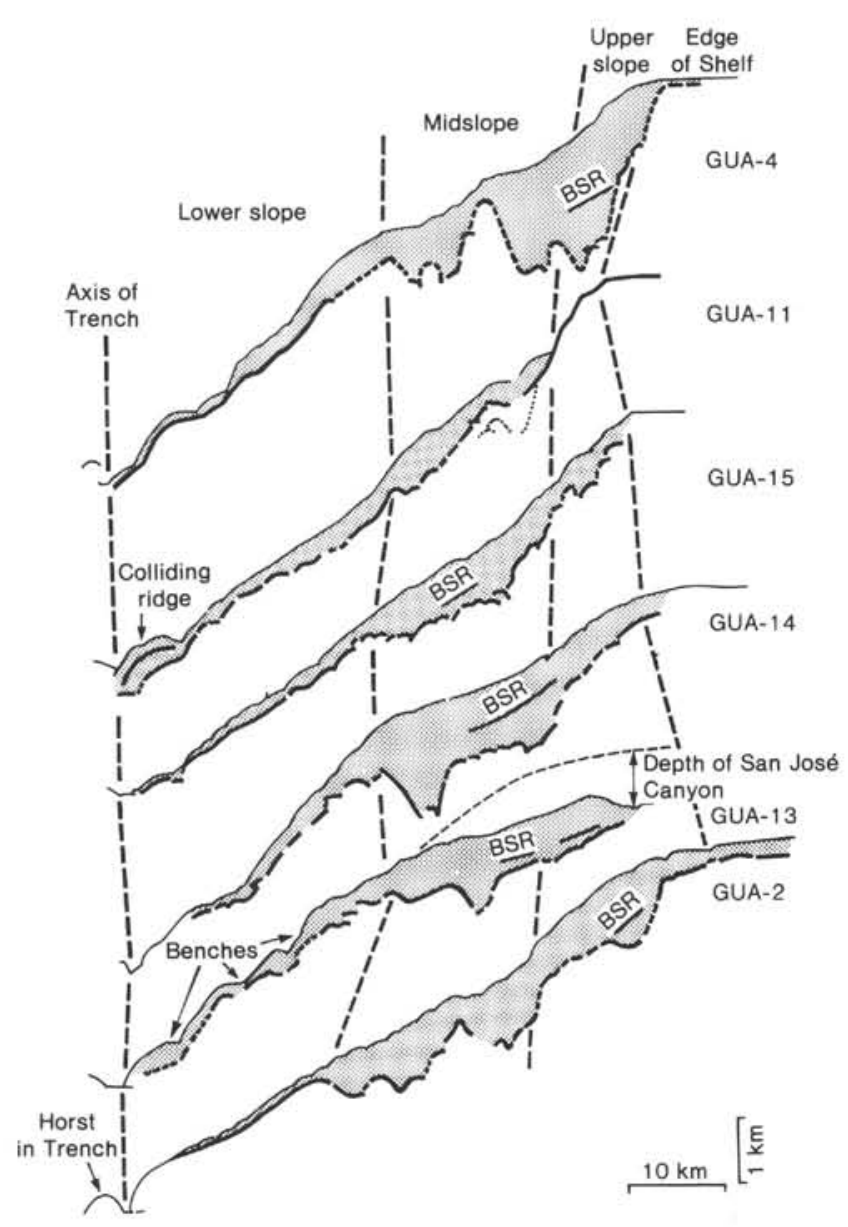

Figure 12. Sections across the Guatemala Trench landward slope along seismic records showing the base of the slope deposits; BSR = bottom-simulating reflector. Vertical exaggeration, $\times$ 13.5. (After von Huene et al., 1982.)

bounding the modern coast of the Santa Elena and Nicoya peninsulas. Offshore from southeastern Nicoya Peninsula a prominent structural high parallels the coast (Case and Holcombe, 1980). This structure is perpendicular to the Trench, which is shifted along a left strikeslip fault. This fault seems to be active.

Plio-Pleistocene to Holocene uplift is also documented by the beach and offshore sandstones of the Montezuma Formation, which today are uplifted more than $100 \mathrm{~m}$, as well as by Holocene uplifted beaches in the MontezumaCabo Blanco area (Fischer, 1980; Battistini and Bergoeing, 1982).

In this region the University of Texas seismic lines NCY-1 and CR-5 cross the extension of the on-land geology (Figs. 9 and 10). Line NCY-1 parallels the geologic cross-section. At most there are $20 \mathrm{~km}$ between NCY-1 and the on-land geology. The faults on land can be extended to the seismic line with some confidence. The unconformity in the sedimentary cover appears to correspond offshore to the boundary between the sediments and the volcanic rocks. On the other hand, the unconformity under the Montezuma Formation (Goudkoff and Porter, 1942) appears as a strong erosional surface (U2 of lines 5 and 6, Fig. 10) above the Upper Cretaceous-
Paleocene sediments and the igneous basement. All the post-Paleocene structures appear to be normal faults, which are cut by the erosion surface. Figure 14 summarizes the evolution of the southeastern Nicoya Peninsula and extends it to the nearby NCY-1 record. Thus we propose that there are two stages of normal faulting in the Nicoya Peninsula region. The first took place before deposition of the Montezuma Formation. Comparison between lines 4,5 , and 6 (Fig. 10) points out that this phase of normal faulting affected the present continental shelf.

The second phase of normal faulting took place after deposition of the Montezuma and Barra Honda formations. It is associated with the Rio Tempisque subsidence and with the second phase of subsidence of the slope. It resulted from the Nicoya Peninsula on-land geology. Also, a comparison with offshore seismic records off Costa Rica show that the post-lower Eocene rocks have been tilted in two stages. We believe that the tilting produced the Middle America Trench landward slope, the Rio Tempisque subsidence, and also the large uplifted dome structure of Nicoya Peninsula (Kuijpers, 1980). In our speculative model (Fig. 14), the shelf as well as the continental slope appear to have resulted mainly from the tilting. The first erosional phase could explain the lack of Paleocene sediment in the Leg 84 drilled holes even though Paleocene deposits are very thick at the Esso Petrel Well (Seely et al., 1974). Thus evidence for preOligocene erosion, occurring mainly on land in Costa Rica, would be found on the continental slope off Guatemala; this erosion would later have ceased due to slope subsidence. Seabeam data from Leg 67 and 84 areas (Aubouin, Stephan, et al., 1982) give evidence for the post-Oligocene tectonic history of the Middle America Trench inner wall. Scarps associated with benches of the lower slope are concave seaward. Only normal faulting related to collapse can produce this topographic feature.

Thus in Costa Rica and Guatemala normal faulting associated with tilting and collapse is the main tectonic feature affecting the Campanian-Tertiary sedimentary cover.

\section{CONCLUSIONS}

We previously defined the slope basement wedge off Costa Rica (Fig. 10 and 12) from the seismic data collected by the University of Texas. The slope basement wedge is inferred to be equivalent to the Nicoya Complex on the basis of (1) its high sonic velocity and (2) the proximity between the onshore and offshore data (Figs. 9 and 10). On the landward slope of the Middle America Trench off Guatemala the slope basement wedge was found to consist of ophiolitic rocks (Aubouin, von Huene et al., 1982a, b) down to the toe of the continental slope (Fig. 11). Harzburgite, cumulate peridotite, gabbro, dolerite, and amphibolite-facies metamorphic rocks have been recognized (Bourgois et al., this volume) on the basis of petrologic and geochemical analyses. These rocks resemble in petrography, chemistry, and age the mafic and ultramafic rocks of Santa Elena Peninsula. Analyses of the on-land lithostratigraphy and structure of the Nicoya Complex show that its most important tectonic features are the large Santa Elena and Matapalo nappes emplaced 


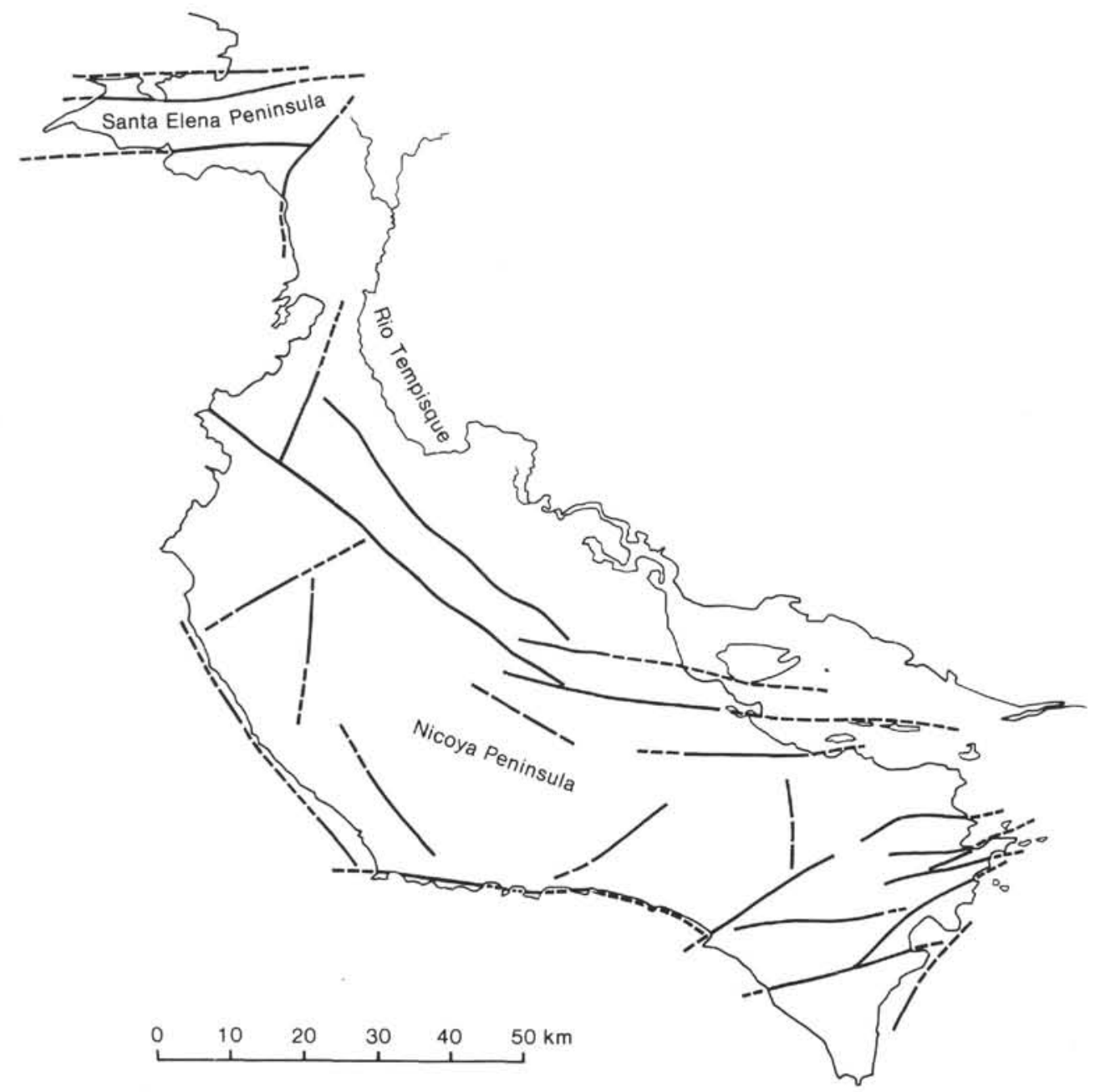

Figure 13. Lineaments across Santa Elena and Nicoya peninsulas from the Landsat imagery analysis.

from north to south. These dominant structures are considered to be products of a post-late Santonian tectonic stress because the lowest Esperanza unit contains Santonian rocks. These results lead us to interpret the landwarddipping slabs of rock (Fig. 15B) within the upper slope off Guatemala (Ladd et al., 1982) to be nappes. The landward-dipping reflectors of the Guatemala slope could be equivalents of the Santa Elena-Matapalo overthrusts (Fig. 15C). This interpretation is consistent with drilling results, magnetic data, and structural features.

The sedimentologic and lithostratigraphe studies of the sediments overlying the Nicoya Complex give evidence for the Campanian-Tertiary geologic history of Costa Rica. The upper Campanian-Maestrichtian El Viejo Formation apparently formed in a shallow-water and terrestrial environment on northern Nicoya and Santa Elena peninsulas, whereas the coeval Sabana Grande Formation to the south is more likely of deep-water origin. The Paleocene Rivas, Las Palmas, and Samara formations document a deep-water clastic environment. The post-Oligocene Montezuma and Barra Honda formations appear to be shallow-water sediments. Two strong unconformities are a prominent geologic feature of the upper Senonian-Tertiary rocks of the Nicoya and Santa
Elena peninsulas. The lower unconformity is below the Sabana Grande Formation, and the second one is below the Barra Honda and Montezuma formations. Late Senonian-Tertiary tectonic history was dominated by normal faulting, which occurred in two stages (Fig. 14). The first stage is post-Paleocene in age, and the second has probably been active for the last 35 m.y. A strong erosional phase separates the two stages of normal faulting. Seabeam data, drilling, and seismic records all support normal faulting offshore Central America. Thus it is proposed that the Middle America Trench is a new type of active margin (Aubouin, Bourgois, et al., 1984), the convergent extensional margin. The structure of the continental slope off Guatemala (Fig. 15A) inferred from the convergent extensional margin hypothesis shows a seaward thinning of the slope basement wedge related to normal faulting. Thus the fundamental mechanism of the slope basement thinning of the convergent extensional margin is apparently the same as that operating on a passive margin. The seaward thinning of the slope sediments, however, leads us to infer that the pre-Oligocene erosion is mainly restricted to the slope (Figs. 10, 11, and 12). Forty to fifty million years ago the present slope could have been a subaerial relief surface. 


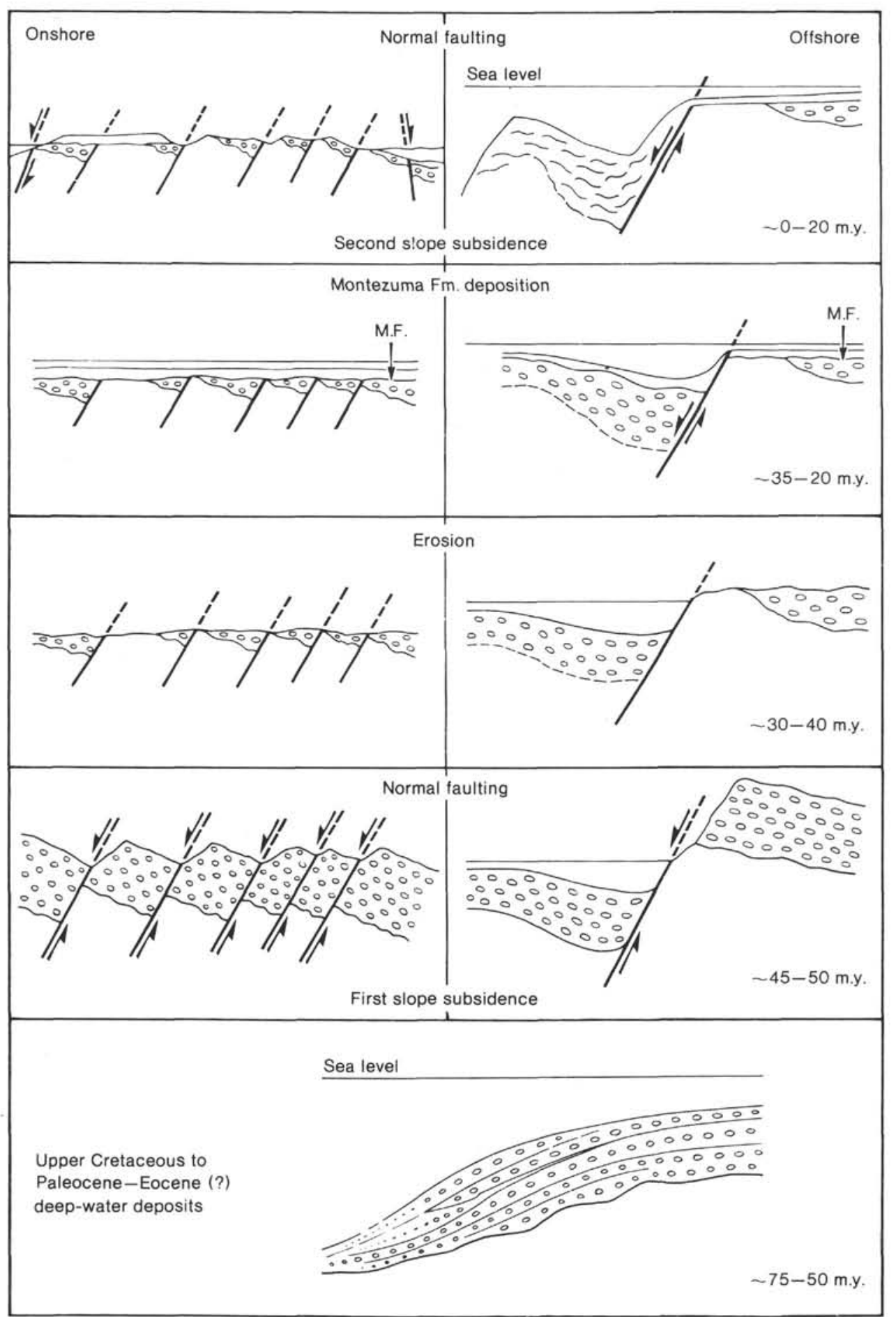

Figure 14. Speculative tectonic evolution for the last 75 m.y. (based on profiles 5 and 6 of Fig. 10). M.F. = Montezuma Formation.

\section{ACKNOWLEDGMENTS}

This research was supported by LA 215 of the Centre National de la Recherche Scientifique (CNRS) and also by the ATP Géophysique et Géologie des Océans (GGO). Field work of P.O.B. was supported by the University of Costa Rica (project No. 02070313 ) and by a travel grant from the Schweizerische Naturfoschende Gesellschaft. The authors have greatly profited from the extensive discussions with Roland von Huene, who made extensive and helpful comments on a draft of the manuscript. We thank Neil Lundberg for his thoughtful, thorough, and extensive review.

\section{REFERENCES}

Aubouin, J., Bourgois, J., and Azéma, J., 1984. A new type of active margin: the convergent extensional margin, as exemplified by the Middle America Trench off Guatemala. Earth Planet. Sci. Lett., $67: 211-218$ 
Aubouin, J., Bourgois, J., von Huene, R. E., and Azéma, J., 1982. La marge pacifique du Guatemala: Un modèle de marge extensive en domaine convergent. C.R. Acad. Sci. Paris, 295:607-614.

Aubouin, J., Stephan, J. F., Roump, J., and Renard, V., 1982. The Middle America Trench as an example of a subduction zone. Tectonophysics. 86:113-132.

Aubouin, J., von Huene, R. E., Azéma, J., Coulbourn, W. T., Cowan, D. S., Curiale, J. A., Dengo, C. A., Faas, R. W., Harrison, W., Hesse, R., Ladd, J. W., Muzilev, N., Shiki, T., Thompson, P. R., and Westberg, J., 1979. Premiers résultats des forages profonds dans le Pacifique au niveau de la fosse du Guatemala (fosse d'Amérique Centrale) (Leg 67 du Deep Sea Drilling project: Mai-Juin 1979). C.R. Acad. Sci. Paris, 289:1215-1220.

Aubouin, J., von Huene, R., Baltuck, M., Arnott, R., Bourgois, J., et al., 1982a. Leg 84 of the Deep Sea Drilling Project, subduction without accretion: Middle America Trench off Guatemala. Nature, (London), 297:458-460.

, 1982b. Subduction sans accrétion: la marge pacifique du Guatemala: Premiers résultats du Leg 84 du Deep Sea Drilling Project (Janvier-Févirer 1982). C.R. Acad. Sci. Paris, 294:803-812.

Azéma, J., Glaçon, G., Tournon, J., Vila, J. M., 1979. Precisiones acerca del Paleoceno de Puerto Quepos y sus alrededores, provincia de Puntarenas, Costa Rica. Inf. Semestral, Julio a Diciembre 1978, Instituto Geografico Nacional, San José, Costa Rica, pp. 77-87.

Azéma, J., Glaçon, G., and Tournon, J., 1981. Nouvelles données sur le Paléocène à Foraminifères de la bordure pacifique du Costa Rica (Amérique Centrale). C.R. Somm. Soc. Géol. France, 3:85-88.

Azéma, J., Origlia, I., Tournon, J., and De Wever, P., 1982. Nouvelles données sur la présence de Crétacé moyen au sein des formations volcano-sédimentaires de l'autochtone relatif de la péninsule de Santa Elena (Costa Rica, Amérique Centrale). 9éme R.A.S.T., Paris, Soc. Géol. France Ed., p. 22.

Azéma, Sornay, J., and Tournon, J., 1979. Découverte d'Albien supérieur à Ammonites dans le matériel volcano-sédimentaire du "complexe de Nicoya" (province de Guanacaste, Costa Rica). C.R. Somm. Soc. Geol. France, 3:129-131.

Azéma, J., and Tournon, J., 1979. Remarques sur la géologie des "massifs anciens” de la marge pacifique du Costa Rica. 7ème R.A.S.T., Lyon, Soc. Géol. France Ed., p. 22.

1980. La péninsule de Santa Elena, Costa Rica: Un massif ultrabasique charrié en marge pacifique de l'Amérique centrale. C.R. Acad. Sci. Paris, 290:9-12.

, 1982. The Guatemalan margin, the Nicoya Complex, and the origin of the Caribbean Plate. In Aubouin, J., von Huene, R. E., et al., Init. Repts. DSDP 67: Washington (U.S. Govt. Printing Office), 739-745.

Battistini, R., and Bergoeing, J. P., 1982. Un exemple de côte à structure faillée, quadrillée et néotectonique active: La côte pacifique du Costa Rica. Bull. Assoc. Géogr. France, 488:199-205.

Bourgois, J., Azéma, J., Tournon, J., Bellon, H., Calle, B., Parra, E., Toussaint, J. F., Glaçon, G., Feinberg, H., de Wever, P., and Origlia, I., 1982. Ages et structures des complexes basiques et ultrabasiques de la façade pacifique entre $3^{\circ} \mathrm{N}$ et $12^{\circ} \mathrm{N}$ (Colombie, Panama et Costa Rica). Bull. Soc. Geol. France, 3:545-554.

Bourgois, J., Calle, B., Tournon, J., and Toussaint, J. F., 1982. The ophiolitic Andes megastructures on the Buga-Buenaventura transverse (Western Cordillera-Valle Colombia). Tectonophysics, 82: 207-229.

Buffler, R. T., unpublished. Geologic structure of the forearc region off the west coast of Costa Rica in the vicinity of the Nicoya Peninsula: results of a multifold seismic reflection. University of Texas at Austin, Contribution No. 537.

Case, J. E., 1974. Oceanic crust forms basement of eastern Panama. Geol. Soc. Am. Bull., 85:645-652.

Case, J. E., and Holcombe, T. L., 1980. Geologic and tectonic map of the Caribbean Region. U.S. Geol. Survey, Reston, VA. Misc. Invest. Maps 1-1100, scale 1:2,500,000.

Crowe, J. C., and Buffler, R. T., unpublished. Regional seismic reflection profiles across the Middle America Trench and convergent margin off Costa Rica. University of Texas at Austin, Contribution No. 537.

de Boer, J., 1979. The outer arc of the Costa Rican orogen (oceanic basement complexes of the Nicoya and Santa Elena peninsulas). Tectonophysics, 56:221-259.
Dengo, G., 1962a. Estudio Geologico de la Region de Guanacaste, Costa Rica. Instituto Geografico Nacional, San José, Costa Rica. 1962b. Tectonic-igneous Sequence in Costa Rica. Petrologic Studies: a Volume to Honor A. F. Buddington. Geol. Soc. Am., 133-161.

1973. Estructura geologica, historia tectonica y morfologia de America central. Instituto Centroamericano de Investigacion y Tecnologia Industrial (ICAITI), Mexico, Buenos Aires (Centro Regional de Ayuda Tecnica), 2e éd.

Fischer, R., 1980. Recent tectonic movements of the Costa Rican Pacific coast. Tectonophysics, 70:25-33.

Galli, C., 1977. Edad de emplazamiento y periodo de acumulacion de la ofolita de Costa Rica. Rev. Cienc. Tec., Univ. de Costa Rica, San José, 1:81-86.

1979. Ophiolite and island arc volcanism in Costa Rica. Bull. Geol. Soc. Am., 90:444-452.

Galli, C., and Schmidt-Effing, R., 1977. Estratigrafica de la cubierta sedimentaria supra-ofiolitica cretacica de Costa Rica. Rev. Cienc. Tec., Univ. de Costa Rica, San José, 1:87-96.

Goudkoff, P. P., and Porter, W. W., 1942. Amoura shale of Costa Rica. Am. Assoc. Pet. Geol. Bull., 26:1647-1655.

Gursky, H. J., Schmidt-Effing, R., Strebin, M., and Wildberg, H., 1982. The ophiolite sequence in northwestern Costa Rica (Nicoya Complex): outlines of stratigraphical, geochemical, sedimentologi$\mathrm{cal}$ and tectonic data. Quinto Cong. Lat. Am. de Geologia Argentina Acta, 3:607-619.

Harrison, J. V., 1953. The geology of Santa Elena Peninsula in Costa Rica, Central America. Proc. Pac. Sci. Congr. 7th, Auckland-Christchurch, pp. 102-114.

Hein, J., Kuijpers, E. P., Denyer, P., and Sliney, R. E., 1983. Petrology and geochemistry of Cretaceous and Paleocene cherts from western Costa Rica. In Iijima, A., Hein, J. R., and Siever, R. (Eds.), Siliceous Deposits in the Pacific Region: Amsterdam, (Elsevier), pp. 143-174.

Henningsen, D., and Weyl, R., 1967. Ozeanische Kruste im NicoyaKomplex von Costa Rica (Mittelamerika). Geol. Rundsch., 57:33-47.

Hey, R., Johnson, G. L., and Lowrie, A., 1977. Recent plate motions in the Galapagos area. Geol. Soc. Am. Bull., 88:1385-1403.

Ibrahim, A. K., Latham, G. V., Ladd, J., 1979. Seismic refraction and reflection measurements in the Middle America Trench offshore Guatemala. In Ahrens, T. J. (Ed.), J. Geophys, Res., 84(B10): 5643-5649.

ICAITI, 1968. Mapa Geologico de Costa Rica. Instituto Geografico Nacional.

Kuijpers, E. P., 1980. The geological history of the Nicoya ophiolite complex, Costa Rica, and its geotectonic significance. Tectonophysics, 68:233-255.

Kuijpers, E. P., and Denyer, P., 1979. Volcanic exhalative manganese deposits of the Nicoya ophiolite complex, Costa Rica. Econ. Geol., 74:672-678.

Ladd, J. W., Ibrahim, A. K., McMillen, K. J., Latham, G. V., von Huene, R. E., Watkins, J. S., Moore, J. C., Worzel, J. L., 1978. Tectonics of the Middle America Trench offshore Guatemala. International Symposium Guatemala, 4 February, Earthquake and Reconstruction Process, 2, Guatemala City, May 1978.

Ladd, J. W., Ibrahim, A. K., McMillen, K. J., Latham, G. V., and von Huene, R. E., 1982. Interpretation of seismic reflection data of the Middle America Trench offshore Guatemala. In Aubouin J., von Huene R. E., et al., Init. Repts. DSDP, 67: Washington (U.S. Govt. Printing Office), 675-689.

Lloyd, J. J., 1963. Tectonic history of the south Central American orogen. In Childs, O. E., and Beebe, B. W. (Eds.), Backbone of the America's. Am. Assoc. Pet. Geol. Mem., 2:88-100.

Lexique Stratigraphique International, 1960. Amérique Centrale par Hoffstetter, R., Dengo, G., Dixon, C. G., Meyer-Abich, H., Weyl, R., Woodring, W. P., Zoppis Bracci, L., (Fasc. 2a), In Hoffstetter, R. (Director), Amérique Latine (Vol. 5), Paris (CNRS).

Lundberg, N., 1982. Evolution of the slope landward of the Middle America Trench, Nicoya Peninsula, Costa Rica. In Leggett, J. L. (Ed.), Thench Forearc Geology: Sedimentation and Tetonics on Modern and Ancient Active Plate Margins. Spec. Pub. No. 10, Geol. Soc. London, pp. 131-147.

McBirney, A. R., and Williams, H., 1965. Volcanic history of Nicaragua. Univ. California Pub. Geol. Sci., 55:1-65. 
McDonald, D. F., 1920. Informe final geologico y geografico de Costa Rica. Rev. Costa Rica, 2, San José, Costa Rica.

McNally, K. D., and Minster, J. B., 1981. Nonuniform seismic slip rates along the Middle America Trench. J. Geophys. Res., 86: 4949-4959.

Minster, J. B., and Jordan, T. H., 1978. Present-day plate motions. J. Geophys. Res., 83:5331-5354.

Moore, G. F., Lonsdale, P., and von Huene, R., 1982. Near bottom observations of the Middle America Trench off Guatemala. In Aubouin, J., von Huene, R., et al., Init. Repts. DSDP, 67: Washington (U.S. Govt. Printing Office), 707-718.

Moore, J. C., Watkins, J. S., Bachman, S. B., Beghtei, F. W., Butt, A., Didyk, B. M., Leggett, J. K., Lundberg, N., McMillen, K. J., Niitsuma, N., Shephard, L. E., Shipley, T. H., Stephan, J. F., and Stradner, H., 1979. Progressive accretion in the Middle America Trench, southern Mexico. Nature (London), 281:638-642.

Mora, S., 1978. Estudio geologico de los cerros Barra Honda y alrededores, Guanacaste, Costa Rica (Tesis de Bachillerato); Escuela de Geologia, Instituto Costarricense de Electricidad.

1981. Barra Honda. Editorial Universidad Estatal a Distancia, San José, Costa Rica.

Pichler, H., and Weyl, R., 1973. Petrochemical aspects of Central American magmatism. Geol. Rundschau, 62(2):357-396.

Rivier, F., 1983. Sintesis geologica y mapa geologico del area del Bajo Tempsique, Costa Rica. Inf. Semestrol Enero a Junio 1983, Instituto Geografico Nacional, San José, Costa Rica, pp. 7-30.

Schmidt-Effing, R., 1975. El primer hallazgo de amonites en America Central Meridional y notas sobre las facies cretacicas en dicha region. Inf. Semestral Enero a Junio, 1974, Instituto Geografico Nacional, San José, Costa Rica, pp. 52-61.

1979. Alter und Genese des Nicoya Komplexes, einer ozeanischen Paläokruste (Oberjura bis Eozän) im Sudlichen Zentralamerika. Geol. Rundschau (Stuttgart), 68(2):457-494. 1980. Radiolarien der Mittel-Kreide aus dem Santa Elena Massiv von Costa Rica. N. Jahrb. Geol. Palaont. Abh., 160(2): 241-257.

Schmidt-Effing, R., Gursky, H. J., Strebin, M., and Wildberg, H., 1981. The ophiolites of southern Central America with special reference to the Nicoya Peninsula (Costa Rica). Trans. 9th Carib. Geol. Conf., Santo Domingo, Oct. 1980, Rép. Dominicaine, pp. 423-430.
Seely, D. R., Vail, P. R., and Walton, G. G., 1974. Trench slope model. In Burk, C. A., and Drake, C. L. (Eds.), The Geology of Continental Margins: New York (Springer-Verlag), pp. 249-260.

Shipley, T. H., Ladd, J. W., Buffler, R. T., and Watkins, J. S., 1982. Tectonic processes along the Middle America Trench inner slope. In Leggett, J. K. (Ed.), Trench-Forearc Geology: Sedimentation and Tectonics on Modern and Ancient Active Margins. Spec. Publ. No. 10, Geol. Soc. London, pp. 95-106.

Sprechmann, P., 1982. Estratigrafia de Costa Rica, I: Unidades estratigraficas sedimentarias. Sth Latinamerican Geol. Congr., Argentina, Actas, 1:55-71.

Stibane, F. R., Schmidt-Effing, R., and Madrigal, R., 1977. Zur stratigrafisch-tektonischen Entwicklung der Halbinsel Nicoya (Costa Rica) in der Zeit von ober-Kreide bis unter-Tertiär. Giessener Geol. Schr., 12:315-358.

Tournon, J., and Azéma, J., 1980. Sobre la estructura y la petrologia del macizo ultrabasico de Santa Elena, Provincia de Guanacaste, Costa Rica. Inf. Semestral Enero a Junio 1980, Instituto Geografico Nacional, San José, Costa Rica, pp. 17-54.

von Huene, R. E., Aubouin, J., Azéma, J., Blackinton, G., Carter, J. A., Coulbourn, W. T., Cowan, D. S., Curiale, J. A., Dengo, C. A., Faas, R. W., Harrison, W., Hesse, R., Hussong, D. M., Ladd, J. W., Muzylov, N., Shiki, T., Thompson, P. R., and Westberg, J., 1980. Leg 67: The Deep Sea Drilling Project Mid-America Trench transect off Guatemala. Geol. Soc. Am. Bull., 91:421-422.

von Huene, R. E., Ladd, J., and Norton, I., 1982. Geophysical observations of slope deposits, Middle America Trench off Guatemala. In Aubouin, J., von Huene, R. E., et al., Init. Repts. DSDP, 67: Washington (U.S. Govt. Printing Office), 719-732.

Wager, L. R., and Brown, G. M., 1968. Layered Igneous Rocks: Edinburg-London (Oliver and Boyd).

Weyl, R., 1964. Die paläogeografische Entwicklung des Mittelamerikanisch-Westindischen Raumes. Geol. Rundschau, 54:1213-1240. 1966. Ozeanische Kruste in südlichen mittelamerika? $N$. Jarhb. Geol. Palaontal. Monatsh., 275-281. 1969. Magmatische Föderphasen und Gesteinschemismus in Costa Rica (Mittel-amerika). N. Jarhb. Geol. Palaontol. Monatsh., 7:423-446

1980. Geology of Central America. Berlin-Stuttgart (Gebr. Borntraeger).

Date of Initial Receipt: 26 July 1983

Date of Acceptance: 8 February 1984 

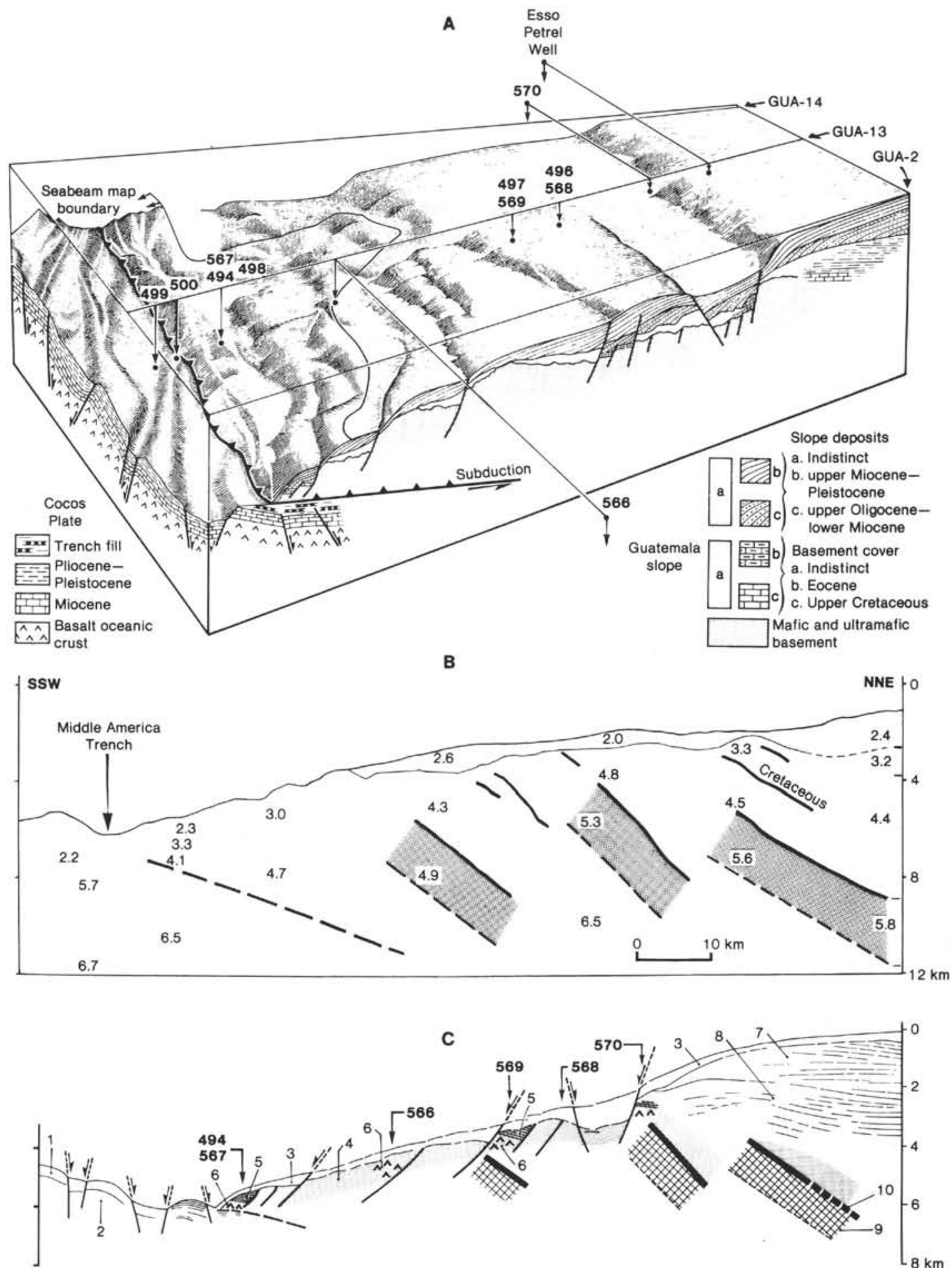

Figure 15. The convergent extensional margin model (after Aubouin, Bourgois et al., 1982). A. Block diagram showing the convergent zone between the Cocos and Caribbean plates in the Middle America Trench off Guatemala. (After Aubouin, Bourgois, et al., 1982). B. Summaries of seismic reflection and refraction studies showing velocity structure and major landward-dipping reflectors on the Legs 67 and 84 transects (after Ladd et al., 1982). C. Interpretation of the structure of the Guatemalan margin. The major landward-dipping reflectors are interpreted as thrust faults bringing pre-Campanian ophiolitic slabs above Upper Jurassic to Upper Cretaceous oceanic rocks of the Matapalo or Esperanza unit, as on land in Costa Rica. (1) Miocene-Pleistocene sedimentary cover of the Cocos Plate; (2) basalt; (3) Pliocene-Pleistocene slope deposits; (4) acoustic basement; (5) upper Senonian-Miocene sediments; (6) ophiolitic rock; (7) Oligocene and Miocene forearc sediment; (8) Paleocene and Eocene forearc sediment; (9) interpreted as a Matapalo unit remnant on the basis of magnetic and gravity data; (10) major reflectors interpreted as a pre-Campanian overthrusting of the Santa Elena peridotite onto the Matapalo and/or Esperanza unit. 